\title{
Impurity Effects on Alumina Scale Growth ${ }^{* \dagger}$
}

\author{
Peggy Y. Hou \\ Materials Sciences Division \\ Lawrence Berkeley National Laboratory \\ Berkeley, CA 94720
}

\begin{abstract}
Most high temperature resistant alloys oxidize to form an external alumina layer, or scale, whose slow growth protects the underlying alloy from continued aggressive oxidation. The growth of the $\mathrm{Al}_{2} \mathrm{O}_{3}$ scale is controlled by the transport of oxygen inward and aluminum outward through it, with the rate dominated by the fastest diffusing specie down the fastest path. Components in the alloy can be incorporated into the growing $\mathrm{Al}_{2} \mathrm{O}_{3}$ layer, hence affect the transport rates of oxygen and/or aluminum. This paper summarizes existing experimental data to assess the possible effect of these incorporated impurities on the growth rate and transport properties of $\mathrm{Al}_{2} \mathrm{O}_{3}$ scales formed on $\mathrm{Fe}, \mathrm{Ni}$ and Pt based alloys. The amount and distribution of the alloy base metal, sulfur impurity and reactive elements, such as $\mathrm{Hf}, \mathrm{Y}, \mathrm{Zr}$ and $\mathrm{Ce}$, in the alumina scale are evaluated. Their effect on the oxidation and transport rates through the scale are discussed and compared with $\mathrm{Al}$ and $\mathrm{O}$ diffusion rates deduced from creep studies.
\end{abstract}

\section{INTRODUCTION}

All metallic components that operate at elevated temperatures rely on the formation of a slow-growing, stable and adherent surface oxide to protect it against excessive material loss due to corrosion. At temperatures above $900^{\circ} \mathrm{C}, \mathrm{Al}_{2} \mathrm{O}_{3}$-forming alloys are most often employed due to the relative ease for alumina to form into a complete layer and the slow growth rate and long-term chemical stability of $\mathrm{Al}_{2} \mathrm{O}_{3}$. There are mainly two types of commercial $\mathrm{Al}_{2} \mathrm{O}_{3}$-forming alloys: the aluminides, such as $\mathrm{Fe}-\mathrm{Ni}$ - and Pt- $\mathrm{Al}$, and the MCrAlX type alloy, where the addition of about $20 \mathrm{at} \% \mathrm{Cr}$ reduces the amount of $\mathrm{Al}$ necessary to establish the protective $\mathrm{Al}_{2} \mathrm{O}_{3}$ layer to no more than $10 \mathrm{at} \%{ }^{1}$. "M" in this case represents the base metal and it can be a mixture of $\mathrm{Fe}, \mathrm{Ni}$ and $\mathrm{Co}$. " $\mathrm{X}$ " are often small amounts of Ti, Zr, Hf, Y and/or other alloying elements. The growth of alumina scales usually follows parabolic kinetics. Rate constants are normally expressed in terms of sample weight gain in units of $\mathrm{g}^{2} / \mathrm{cm}^{4} \mathrm{~s}$.

\footnotetext{
* Presented at the International Symposium on Science and Technology of Alumina, Schloss Ringberg, Germany, March 17-22, 2002.

${ }^{\dagger}$ Supported by the Director, Office of Energy Research, Office of Science, Division of Materials Sciences, of the U. S. Department of Energy under Contract No. DE-AC03-76SF00098.
} 
From the rate constants, an effective diffusion rate can be obtained ${ }^{2}$, such that oxidation studies can be used to gain some knowledge of the transport properties through thermally grown oxides. Contrary to creep, oxidation is controlled by the fastest diffusing specie down the fastest path. Due to the low defect concentration in $\mathrm{Al}_{2} \mathrm{O}_{3}$, diffusion is often dominated by the presence of impurities acting as donors or acceptors ${ }^{3}$. In light of the strong effects of cation doping on the creep rates of polycrystalline alumina ${ }^{4-9}$, it is likely that transport in alumina scales that form by thermal oxidation also depends heavily on the type and level of impurities.

Impurities that are incorporated into the growing alumina scale can come from several different sources. An apparent one is the common surface contaminants that are present before oxidation, such as $\mathrm{Na}$ and $\mathrm{K}^{10}$, but their concentrations are usually low and can vary significantly from test to test. The most abundant impurity source is base metal components, such as $\mathrm{Fe}$, $\mathrm{Ni}$ or $\mathrm{Co}$, which are incorporated as oxides during the initial stage of oxidation ${ }^{11}$. Minor alloying elements added to improve oxidation resistance, often referred to as "reactive elements" 12 , such as $\mathrm{Y}, \mathrm{Ce}$, Hf and $\mathrm{Zr}$, are always found in the alumina scale. Studies have shown that they segregate strongly at alumina grain boundaries and alter the scale growth process ${ }^{13,14}$. Non-metallic impurities that are present in almost all commercial grade alloys may segregate to the scale/alloy interface during oxidation. This has been demonstrated with sulfur ${ }^{15,16}$ whose presence is believed to deteriorate scale adherence ${ }^{17,18}$. However, it is not certain if the segregated sulfur will diffuse or be carried into the scale to exert any effect on scale growth.

Impurities that will be discussed in this paper, with results drawn from $\mathrm{Fe}, \mathrm{Ni}$ and Pt based alloys, are base metal components, reactive elements and sulfur. The purpose is to understand if and how impurities affect $\mathrm{Al}_{2} \mathrm{O}_{3}$ scale growth rate and transport properties, and then compare that to the effects reported by creep studies. A summary is first given of how these elements are incorporated into the growing alumina scale, what are their concentration and distribution as a function of oxidation time and by what degree do they affect the oxidation rate.

\section{IMPURITY INCORPORATION AND EFFECT ON OXIDATION RATE}

\section{Base Metal Components}

All metals and alloys exposed in the ambient atmosphere contain a thin layer of native oxide that is a few nanometers thick. An example is given in Fig. 1(a) for FeCrAl where the surface oxide consists of an outer layer rich in Fe and an inner layer slightly enriched with Cr. Upon heating the sample to elevated temperatures in air or oxygen, this native oxide quickly thickens and aluminum starts to enrich at the scale/alloy interface (Fig. 1b). Further oxidation results in a fully established aluminum oxide layer at the scale/alloy interface (Fig. 1c). Subsequent scale growth only involves thickening of this alumina layer, where all of the initially formed $\mathrm{Fe}$ and $\mathrm{Cr}$ oxides become incorporated into the $\mathrm{Al}_{2} \mathrm{O}_{3}$ layer. Integrating the depth profile curves shown in Fig. 1 over distance, the relative change of scale composition with oxidation time (or scale thickness) can be determined and the results are given in Fig. 2. The oxide scale that developed during the initial stage of oxidation is clearly seen to contain high concentrations of base metals, in this case $\mathrm{Fe}$ and $\mathrm{Cr}$, whose concentrations decrease as the scale develops into a complete 
layer of the thermodynamically most stable oxide, in this case $\mathrm{Al}_{2} \mathrm{O}_{3}$. This process of initial stage base metal oxidation and the subsequent incorporation of their oxides into the final scale are expected for all alloys ${ }^{19}$. The amount that is incorporated depends strongly on the alloy composition, the oxidation temperature and the oxygen partial pressure in the environment, or sometimes even on the alloy surface finish ${ }^{20}$. Behavior on $\mathrm{FeCrAl}$ similar to that reported here has been shown using other surface techniques ${ }^{21,22}$, and $\mathrm{NiCrAl}^{23}$ and $\mathrm{FeAl}^{24}$ also form transient $\mathrm{Ni}$ and $\mathrm{Cr}$ and $\mathrm{Fe}$ oxides respectively.

To determine the distribution of base metal components that are incorporated into the $\mathrm{Al}_{2} \mathrm{O}_{3}$ scale, analytical transmission electron microscopy (TEM) was used to examine $\mathrm{Al}_{2} \mathrm{O}_{3}$ grains and their grain boundaries from oxide pieces that have been spalled and ionmill thinned ${ }^{25}$. This method avoids contaminations that can result from cross-sectional TEM sample preparation. Scales 0.4 to $5 \mu \mathrm{m}$ thick, formed on a $\mathrm{FeCrAl}$ alloy at $1000-$ $1200^{\circ} \mathrm{C}$, were examined. The only impurities detected were $\mathrm{Fe}$ and $\mathrm{Cr}$, and their average concentrations in the $\mathrm{Al}_{2} \mathrm{O}_{3}$ decreased with scale growth, from about 4 to 0.3 at $\%$. This continued decrease in base metal component concentration in the alumina scale is similar to that seen in Fig. 2 on much thinner scales studied using Auger depth profile. Together, the trend indicates that the $\mathrm{Al}_{2} \mathrm{O}_{3}$ scale is becoming purer as it thickens with oxidation time.

The $\mathrm{Fe}$ and $\mathrm{Cr}$ concentrations in the $\mathrm{Al}_{2} \mathrm{O}_{3}$ scale appeared uniform when relatively large areas, i.e. $14 \mu \mathrm{m}$, were examined, but they varied greatly from point to point under a $17 \mathrm{~nm}$ beam size ${ }^{25}$. This kind of distribution was also found for $\mathrm{Ni}$ and $\mathrm{Cr}$ in $\mathrm{Al}_{2} \mathrm{O}_{3}$ formed on $\mathrm{NiCrAl}^{26}$. These local high concentrations probably resulted from small grains of base metal oxides or spinels left from the initial stage of oxidation. The lattice parameter of $\alpha$ $\mathrm{Al}_{2} \mathrm{O}_{3}$ grains within the scale was enlarged with higher concentrations of $\mathrm{Fe}$ and $\mathrm{Cr}^{25}$ suggesting that at least some of these elements are dissolved in the $\mathrm{Al}_{2} \mathrm{O}_{3}$. Due to this random distribution of $\mathrm{Fe}$ and $\mathrm{Cr}$ throughout the scale, segregation at alumina grain boundaries was more difficult to detect. Point analyses were made at many grain boundaries and within the grains adjacent to the boundary for direct comparisons. About $38 \%$ of the boundaries showed higher concentrations of $\mathrm{Fe}$, but none had higher concentrations of $\mathrm{Cr}$. Since $\mathrm{Cr}_{2} \mathrm{O}_{3}$ forms a complete solid solution with $\mathrm{Al}_{2} \mathrm{O}_{3}{ }^{27}, \mathrm{Cr}$ is expected to dissolve in $\mathrm{Al}_{2} \mathrm{O}_{3}$ and not segregate on grain boundaries. Fe may have segregated, but not being able to make distinctions between the charge states of the iron makes our results inconclusive. Recent work by Harmer ${ }^{28}$ using EELS shows that $\mathrm{Fe}^{2+}$ segregates at $\mathrm{Fe}$-doped $\mathrm{Al}_{2} \mathrm{O}_{3}$ grain boundaries, but not $\mathrm{Fe}^{3+}$. The behavior is consistent with the fact that $\mathrm{Fe}^{3+}$ has an appreciable solubility in $\mathrm{Al}_{2} \mathrm{O}_{3}$, about 3-5 at $\%{ }^{29}$, but the solubility is only a few ppm for $\mathrm{Fe}^{2+} .30$

For Pt-based alloys, such as PtAl, the Pt is not expected to oxidize and get incorporated into the scale. However, small amounts of Pt have been found in the gains and on the grain boundaries of $\alpha-\mathrm{Al}_{2} \mathrm{O}_{3}$ that formed on PtAl after 2 hours oxidation at $1200^{\circ} \mathrm{C}^{31}$. The Pt may be incorporated during scale growth or redeposited during crosssectional TEM specimen preparation by ion thinning.

Since base metal oxides are indeed incorporated into $\mathrm{Al}_{2} \mathrm{O}_{3}$ scales, and perhaps even segregate at the oxide gain boundaries, it is therefore possible that they may have an effect on transport, hence on the overall oxidation rate. Whittle and Hindam ${ }^{32}$ compiled 
the rate constants from earlier studies of $\mathrm{Al}_{2} \mathrm{O}_{3}$-forming alloys and showed that the rates scattered over one order of magnitude, but they did not make any distinction between $\mathrm{Al}_{2} \mathrm{O}_{3}$ formed on different types of alloys or alloys with or without reactive elements. Data cited in the Whittle and Hindam paper ${ }^{32}$ are re-evaluated and those representing steadystate growth rates from $\mathrm{Ni}, \mathrm{Fe}$ or Pt based alloys that are undoped with reactive elements are compared with more recently published results and those obtained from our laboratory. These rates are plotted in Figure 3 as a function of the inverse of the oxidation temperature. All of the studies included here are from laboratory tests performed on high purity binary $\mathrm{M}-\mathrm{Al}$ or ternary $\mathrm{M}-\mathrm{Cr}-\mathrm{Al}$ type alloys, so $\mathrm{M}$ (Fe, Ni and $\mathrm{Pt}$ ) and $\mathrm{Cr}$ should be the most abundant impurities incorporated in the $\mathrm{Al}_{2} \mathrm{O}_{3}$ scale. Most tests were carried out in one atmosphere oxygen, but some in air. To void extensive crowding, individual contributions are not identified on this figure, but the works are listed in references 31 and 33-58. Different symbols in Figure 3 distinguish different types of alloys. The data scatter from study to study even for alloys with the same composition. Some general trends, however, are apparent. The most obvious is that PtAl's show the slowest oxidation rates. This is somewhat expected, since even if $\mathrm{Pt}$ is present in the $\mathrm{Al}_{2} \mathrm{O}_{3}$ scale, it should be there as a metal, therefore, not affecting the $\mathrm{Al}$ and $\mathrm{O}$ transport. If the concentration of other impurities is not high or if they don't play any significant role on transport, these rates can be considered as the "intrinsic" oxidation rate of $\mathrm{Al}_{2} \mathrm{O}_{3}$ scales. Comparatively, the $\mathrm{Ni}$ and Fe-based alloys oxidized about 8 and 10 times faster respectively, probably due to some effects of $\mathrm{Ni}$ and $\mathrm{Fe}$ on the transport rates of $\mathrm{O}$ and/or $\mathrm{Al}$. The presence of $\mathrm{Cr}$ does not seem to make any difference on oxidation rates. Fe-based alloys appear to oxidize slightly faster than the Ni-based ones. However, these higher rates may be related to an increase in surface area that resulted from wrinkling of the scale and the underlying alloy ${ }^{59,60}$. FeCrAl and $\mathrm{Fe}_{3} \mathrm{Al}$ type alloys are especially prone to wrinkling. Such increase in surface area can be as high as $10 \%{ }^{60}$, but none of the oxidation rates cited here have been corrected for it.

\section{$\underline{\text { Sulfur }}$}

The segregation of sulfur to growing oxide/metal interfaces has been studied using conventional Auger electron microscopy (AES) with a typical probe size of about $1 \mu \mathrm{m}^{15,16,61,62}$, and with field emission AES of probe sizes $\sim 30 \mathrm{~nm}^{63}$. The chemical composition of the alloy surface was examined after spalling the oxide scale in ultra high vacuum (UHV) by scratching an oxidized specimen surface ${ }^{61,64}$. This technique also allows the oxide side of the interface to be examined by analyzing scale pieces that had flipped over during spalling but remained on the specimen surface. The oxide side contained none to very tiny amounts of segregants, most were found on the metal side of the interface. The built up of sulfur as a function of oxidation time at the $\mathrm{Al}_{2} \mathrm{O}_{3} / \mathrm{FeCrAl}$ and $\mathrm{Al}_{2} \mathrm{O}_{3} / \mathrm{FeAl}$ interfaces, along with representative AES spectra showing typical compositions, are presented in Figure 4. These results were obtained from conventional AES, but the same interface segregation behavior has been confirmed by the small probe of FEAES ${ }^{63}$.

A large amount of sulfur quickly saturated at the $\mathrm{Al}_{2} \mathrm{O}_{3} / \mathrm{FeCrAl}$ interface. The rate was as rapid as one would expect from that of surface segregation, where it is dictated by the diffusion of sulfur in the alloy ${ }^{61}$. The sulfur coverage at the interface was everywhere uniform, whether on interfacial void surfaces or on areas where the scale was in contact 
with the alloy before it spalled in the UHV. Other than sulfur, there were also excess carbon and chromium at the interface. The carbon segregated during cooling and the $\mathrm{Cr}$ co-segregated with sulfur ${ }^{15,65}$. This co-segregation caused excess sulfur to be present at the interface, giving rise to the high concentration that amounts to $\sim 2$ monolayers, where a monolayer is defined as one physical layer on the alloy surface. Similar interfacial composition has been observed for $\mathrm{NiCrAl}$ alloys, but without the high concentration of $\mathrm{C}$ due to a slower diffusion rate of $\mathrm{C}$ in the fcc Ni-based alloy ${ }^{62}$.

For the Fe-Al alloy, sulfur was detected on large interfacial voids at the very early stage, but did not appear at intact oxide/metal interface areas until a complete layer of $\alpha$ $\mathrm{Al}_{2} \mathrm{O}_{3}$ formed at the interface ${ }^{62,63}$, then the sulfur concentration built up slowly with time. Although the $\alpha$ form is the most stable alumina, the first developed alumina layer is always some transition alumina most often identified as $\theta$ or $\gamma-\mathrm{Al}_{2} \mathrm{O}_{3}{ }^{24,66,67}$. With time, $\alpha-\mathrm{Al}_{2} \mathrm{O}_{3}$ nucleates at the scale/alloy interface ${ }^{68}$ until it develops into a complete layer, and the initially formed transition alumina also transforms to the $\alpha$ form with time. The development of an $\alpha$ layer is faster at higher temperatures ${ }^{24}$ and seems to be facilitated by the presence of chromium ${ }^{69,70}$. The fact that sulfur did not start to segregate to the $\mathrm{Al}_{2} \mathrm{O}_{3} / \mathrm{FeAl}$ interface until the establishment of a complete layer of $\alpha-\mathrm{Al}_{2} \mathrm{O}_{3}$ indicates that the process of impurity segregation to growing oxide/metal interfaces is strongly related to scale development. Perhaps it depends on the interface microstructure, as does solute segregation for grain boundary structures ${ }^{71-73}$. Similar results were also obtained for $\mathrm{Fe}_{3} \mathrm{Al}$ type alloys ${ }^{16}$.

With sulfur being clearly concentrated at the scale/alloy interface, especially so for MCrAl type alloys, the question that follows is whether this interfacial sulfur will be incorporated into the oxide as the scale grows inward. It has been suggested that sulfur influences scale growth, both for alumina ${ }^{74}$ and chromia ${ }^{75}$. Using scanning transmission electron microscopy, Fox el al ${ }^{75}$ have found sulfur at $\mathrm{Cr}_{2} \mathrm{O}_{3}$ scale grain boundaries, and Lees ${ }^{76}$ proposed that the presence of sulfur there promotes cation transport at oxide grain boundaries. Whether this is true needs to be confirmed by more studies. Furthermore, whether sulfur is present in the alumina scale is still an open question.

The presence of sulfur within alumina scales have been examined by a few investigations, and these are listed in Table 1 along with any reported effects on the oxidation rate. The data can be separated into three groups. The first compares a normal purity $\mathrm{Fe}_{3} \mathrm{Al}$ alloy before and after a high temperature $\mathrm{H}_{2}$ annealing heat treatment, which is usually done at $1200^{\circ} \mathrm{C}$ for about 100 hours in dry $\mathrm{H}_{2}$ to remove non-metallic impurities. The process reduces the alloy sulfur content to less than $0.2 \mathrm{ppm}$, hence results in a sulfurfree $\mathrm{Al}_{2} \mathrm{O}_{3}$ /alloy interface ${ }^{77}$. The steady state scale growth rate of the $\mathrm{H}_{2}$-annealed $\mathrm{Fe}_{3} \mathrm{Al}$ was $50 \%$ lower than that of the untreated alloy. However, this rate decrease may not be related to sulfur segregation at oxide grain boundaries, since sulfur was also not detected anywhere in the $\mathrm{Al}_{2} \mathrm{O}_{3}$ scale that formed on the untreated alloy ${ }^{25}$.

The second group in Table 1 compares normal purity $\mathrm{FeCrAl}$ alloys ${ }^{25,78}$ with one that has been $\mathrm{H}_{2}$-annealed ${ }^{79}$ and with ones doped with excess sulfur ${ }^{80}$. Varying the alloy sulfur content from $<0.2 \mathrm{ppm}$ to $\sim 1300 \mathrm{ppm}$ did not change the growth rate of the $\mathrm{Al}_{2} \mathrm{O}_{3}$ scale. TEM analyses ${ }^{25,78}$ again did not detect any sulfur in the $\mathrm{Al}_{2} \mathrm{O}_{3}$ except on void surfaces ${ }^{25}$, these voids exist in the $\mathrm{Al}_{2} \mathrm{O}_{3}$ scale with greater numbers within the $\alpha-\mathrm{Al}_{2} \mathrm{O}_{3}$ 
grains than on grain boundaries. The sulfur found on the circumference of these voids was always associated with higher concentrations of $\mathrm{Cr}$ and $\mathrm{Fe}$. It was suggested that these voids nucleated at the scale/alloy interface where $\mathrm{S}$ and $\mathrm{Cr}$ co-segregated and the interface segregants remained on the void surfaces as the voids are being incorporated into the

growing scale ${ }^{25}$. The last group involves deliberately $\mathrm{S}$-doped $\mathrm{NiAl}^{81}$ and $\mathrm{NiCrAl}^{82}$ alloys. In both cases, the oxidation rate increased and sulfur was detected in the alumina scale and was found segregated at the oxide grain boundary.

Before drawing any conclusions from the results in Table 1, it should be noted that sulfur under the TEM beam has been observed to desorb quickly with time ${ }^{81}$. This behavior would make small concentrations of segregated sulfur very difficult to detect. If all the TEM studies that did not detect sulfur were only due to sulfur desorption prior to the analysis, then perhaps sulfur is present at alumina scale grain boundaries and it increases the scale growth rate. Even so, this conclusion can only explain the data for the $\mathrm{Fe}_{3} \mathrm{Al}$ and the Ni-based alloys, but not for the $\mathrm{FeCrAl}$, where growth rates were not altered regardless of the amount of sulfur in the alloy. The effect of $\mathrm{S}$ on the oxidation rate and its incorporation and distribution in the alumina scale are therefore not yet clear.

\section{$\underline{\text { Reactive Elements }}$}

The distribution of oxygen active or reactive elements in $\mathrm{Al}_{2} \mathrm{O}_{3}$ scales has been studied extensively due to their profound effect on the oxidation behavior of $\mathrm{Al}_{2} \mathrm{O}_{3}$ forming alloys ${ }^{12}$. The reactive elements (RE) in concentrations often less than $0.5 \mathrm{at} \%$, can be added as oxide dispersions or as dissolved metals. Przybylski et $\mathrm{al}^{13}$ using analytical TEM on cross-sectional samples were the first to report $\mathrm{RE}$ segregation on $\mathrm{Al}_{2} \mathrm{O}_{3}$ grain boundaries. Similar segregation has since been observed for almost all RE containing alloys. A number of these ${ }^{13,31,35,37,83-90}$ are listed in Table 2 to show the commonality of this behavior, where several types of reactive elements added in different forms in different kinds of alloys were all found to segregate at $\mathrm{Al}_{2} \mathrm{O}_{3}$ grain boundaries. The amount that is segregated has been quantified to be about 0.2 monolayer $^{91}$.

Most of the works included in Figure 3 also studied the effect of RE on oxidation rates. When all these rates on RE-doped and undoped Fe, Ni and Pt alloys are compared and plotted on Fig. 3, the result is a scatter band about two orders of magnitude wide that shows no apparent effect of RE on scale growth rate. This was exactly the conclusion made by Whittle and Stringer ${ }^{12}$ and later by Whittle and Hindam ${ }^{32}$. The reason may be due to differences in the process of adding RE to the alloys. The distribution ${ }^{92}$ and concentration $^{34}$ of RE in alloys are extremely critical for their effectiveness on oxidation. The same RE incorporated in different types of alloys may also show different effects ${ }^{93}$. If more recent data ${ }^{33,35,36,39,40,43,46}$ with or without RE addition obtained from the same research group on the same type of alloy are compared, the results show consistent reduction of RE on the oxidation rate. These are summarized in Table 3. No distinction was made on the different types of RE, even though some RE may be more effective than others in some cases. Hafnium, for example, has been shown to be exceptionally effective in NiAl alloys, reducing the oxidation rate by almost a factor of ten ${ }^{93}$. However, the behavior of different RE's in different alloys has not been clearly characterized, and there is not a trend indicating which RE is more effective in what type of alloy. The rates shown in Table 3 are averages obtained from all the cited experimental data. They could be from 
several tests of an undoped alloy, or from alloys doped with different reactive elements. These are all causes for the relatively large error bars associated with some of the rate constants. Still, a clear trend can be seen from these results showing that all RE additions in $\mathrm{Ni}$ and Fe-based alloys reduce the oxidation rate by about a factor of two. On the PtAl, addition of $\mathrm{Zr}$ reduced the rate by a factor of four. Unfortunately only one set of data exist for this alloy, so it is premature to conclude that the RE effect on scale growth rate is greater on Pt-based than on Ni or Fe-based alloys.

\section{TRANSPORT RATES THROUGH ALUMINA SCALES}

The grain size of transition alumina that grows initially on alloy surfaces upon oxidation is extremely fine, in the range of a few nanometers ${ }^{23,26}$. The $\alpha-\mathrm{Al}_{2} \mathrm{O}_{3}$ grains that first nucleated at the scale/alloy interface are sub-micron in size ${ }^{68}$. Even with more mature scales, i.e. those that have grown to several microns thick, the oxide grain size is still no more than one or two microns ${ }^{37,38}$. Owing to these small grain sizes, grain boundaries have always been considered the dominant transport process through alumina scales ${ }^{1,2}$.

The growth of an $\mathrm{Al}_{2} \mathrm{O}_{3}$ oxide scale that follows parabolic kinetics is controlled by the diffusion of $\mathrm{O}$ and $\mathrm{Al}$ through the scale layer according to the following equation

$$
k_{p}=\int_{P_{O_{2}}}\left[1.5\left(D_{L}^{A l}+\frac{\delta D_{b}^{A l}}{d}\right)+\left(D_{L}^{O}+\frac{\delta D_{b}^{O}}{d}\right)\right] d \ln P_{O_{2}}
$$

where $k_{p}$ is the parabolic rate constant, $d$ the oxide grain size and D's the respective diffusivities. Assuming the $\mathrm{D}$ 's are not functions of $\mathrm{P}_{\mathrm{O} 2}$ and that the contribution from lattice diffusion is insignificant, an effective diffusivity, $\mathrm{D}_{\text {eff }}$, which is a combination of the boundary diffusivities of $\mathrm{Al}$ and $\mathrm{O}$, can be obtained as

$$
D_{\text {eff }}=k_{p} d / \ln P_{O_{2}}
$$

The $\mathrm{P}_{\mathrm{O} 2}$ is that of the oxygen potential difference across the alumina scale. The parabolic rate constant, $\mathrm{k}_{\mathrm{p}}$, in its usual units of $\mathrm{g}^{2} \mathrm{~cm}^{-4} \mathrm{~s}^{-1}$ can be converted to the units of D's in $\mathrm{cm}^{2} / \mathrm{s}$ using the density of alumina. Assuming thermodynamic equilibrium at the $\mathrm{Al}_{2} \mathrm{O}_{3}$ /alloy interface, the $\mathrm{P}_{\mathrm{O} 2}$ there would be that of the dissociation pressure of $\mathrm{Al}_{2} \mathrm{O}_{3}$ at the oxidation temperature. From most reported microstructure of oxide scales, the average oxide grain size can be taken as roughly $0.5,1,1.5$ and $2 \mu \mathrm{m}$ respectively for oxidations at 1000, 1100, 1200 and $1300^{\circ} \mathrm{C}$. The range of $\mathrm{D}_{\text {eff }}$ thus calculated using Eq. 2 from the range of $\mathrm{k}_{\mathrm{p}}{ }^{\prime} \mathrm{s}$ shown in Fig. 3 is presented as a shaded area in Fig. 5. On this figure are also plotted grain boundary diffusivities deduced from creep studies. The thick solid line is the boundary diffusivity of $\mathrm{Al}$ complied by Cannon and Coble ${ }^{94}$ from $\mathrm{MgO}$-doped alumina. Results from works using undoped high purity $\mathrm{Al}_{2} \mathrm{O}_{3}$ also fall closely to this line ${ }^{94}$. Aluminum boundary diffusivity deduced from creep studies on $\mathrm{Fe}, \mathrm{Ni}, \mathrm{Cr}$ and $\mathrm{Y}$ and $\mathrm{La}$-doped $\mathrm{Al}_{2} \mathrm{O}_{3}$ are also included ${ }^{94,95}$. It is seen that $\mathrm{Cr}^{6}, \mathrm{Ni}^{7}$ or small amounts of $\mathrm{Fe}^{6}$ additions have little effects on $\delta \mathrm{D}_{\mathrm{b}}{ }^{\mathrm{Al}}$. However, with increasing Fe content ${ }^{6}, \delta \mathrm{D}_{\mathrm{b}}{ }^{\mathrm{Al}}$ can be raised appreciably higher and even more so under lower $\mathrm{P}_{\mathrm{O} 2}$, where $\mathrm{Fe}^{2+}$ rather than $\mathrm{Fe}^{3+}$ is believed to be the dominant specie. On the other hand, reactive elements, such as $\mathrm{Y}$ and $\mathrm{La}^{8,9}$, significantly reduce $\delta \mathrm{D}_{\mathrm{b}}{ }^{\mathrm{Al}}$. It is seen that the rates calculated from oxidation are about one order of 
magnitude above the $\mathrm{Mg}, \mathrm{Ni}, \mathrm{Cr}$-doped and undoped $\mathrm{Al}_{2} \mathrm{O}_{3}$, but agree better with that of the $2 \% \mathrm{Fe}$-doped $\mathrm{Al}_{2} \mathrm{O}_{3}$. The $\delta \mathrm{D}_{\mathrm{b}}{ }^{\mathrm{O}}$ values cannot be determined from diffusional creep studies, because the rate is usually controlled by the transport of Al. When creep rates are significantly higher with dopants or co-dopants, such as $\mathrm{Fe}$ and $\mathrm{Ti}^{5}$, the boundary diffusion of oxygen may become important. Gordon and co-workers ${ }^{5,6}$ have estimated $\delta \mathrm{D}_{\mathrm{b}}{ }^{\mathrm{O}}$ to be in the range of $10^{-14}$ to $>10^{-13}$ at $1450^{\circ} \mathrm{C}$. These values agree well with the upper bound of the $\mathrm{D}_{\text {eff }}$ deduced from oxidation. Creep studies that resulted with even higher rates ${ }^{96}$ may have been caused by other deformation mechanisms.

A critical question concerning $\mathrm{D}_{\text {eff }}$ is the relative contribution of $\mathrm{O}$ and $\mathrm{Al}$ transport through the oxide scale during scale growth. From several earlier inert Pt marker studies ${ }^{57,97}, \alpha-\mathrm{Al}_{2} \mathrm{O}_{3}$ was believed to grow predominantly by $\mathrm{O}$ inward diffusion, since markers that was placed on the alloy surface prior to oxidation remained on the scale surface afterwards, indicating scale inward growth. Owing to the slow oxygen lattice diffusivity found by tracer studies ${ }^{98}$, the transport path was presumed to be the alumina grain boundaries. The minor amount of aluminum outward transport is believed to contribute to scale lateral growth, causing extensive scale convolution, or wrinkling ${ }^{54}$. Based on the degree of such convolution, whether the scale is detached from the substrate or wrinkled with it, the extent of lateral growth on polycrystalline $\mathrm{FeCrAl}$ alloy, for example, can be as high as $20-50 \%{ }^{59,95}$. This shows that the amount of Al outward transport is not trivial. More recent two-stage oxidation studies using ${ }^{18} \mathrm{O} /{ }^{16} \mathrm{O}{ }^{99-105}$ indicated more clearly that a considerable amount of $\mathrm{Al}$ outward transport indeed occurs during scale growth. In these studies, the oxidation at each stage is done in an atmosphere enriched with one of the oxygen isotopes. The isotope distribution throughout the scale is subsequently determined using spectroscopic methods. Secondary ion mass spectroscopy (SIMS) is the most commonly employed technique ${ }^{101,103-105}$. Secondary neutrals mass spectroscopy $^{102}$ (SNMS) and other techquies ${ }^{99,100}$ have also been used. From the location and the distribution profile of the second stage isotope, the dominant transport specie and its path can be determined ${ }^{100,106,107}$. A typical profile from the results of Quakakkers et $\mathrm{al}^{102}$ is used in Figure 6 as an illustration. The alumina scale was formed at $1000^{\circ} \mathrm{C}$ on a $\mathrm{FeCrAl}$ alloy after oxidation first in ${ }^{16} \mathrm{O}_{2}$ for 2.5 hours to ensure a completely transformed and stable $\alpha-\mathrm{Al}_{2} \mathrm{O}_{3}$ layer, then without cooling, the specimen was continually oxidized in ${ }^{18} \mathrm{O}_{2}$ for 5 hours to allow new oxides to grow so its location can be later determined. A large peak of the second isotope, in this case ${ }^{18} \mathrm{O}$, is present at the scale/gas interface. Portions of it comes from oxygen isotope exchange, but due to the slow rate of this process ${ }^{107}$ its contribution should be small. The majority of ${ }^{18} \mathrm{O}$ found at the outer surface is therefore due to new oxide formation from the Al that diffused through the scale with the oxygen from the atmosphere. A significant amount of ${ }^{18} \mathrm{O}$ also exists within the first formed oxide and at the scale/alloy interface. This is the result of oxygen diffusion through the $\mathrm{Al}_{2} \mathrm{O}_{3}$ scale forming new oxides at the scale/alloy interface. If the outer and inner portions are integrated and their areas compares, one obtains an outward to inward growth ratio of 0.45 . This method is of course not quantitatively precise, but can be used to compare the effect of dopants on the transport properties through alumina scales.

With the addition of reactive elements, a significant amount of $\mathrm{Al}$ outward transport is reduced. Table 4 summarizes the percentage of outward growth calculated 
from oxygen isotope profiles from several different reports ${ }^{100,102,104}$. Although the absolute percentage calculated this way is not exact, the amount of reduction caused by RE additions can be trusted. In all cases, $\mathrm{RE}$ addition in the alloy, consequently its incorporation and segregation at the $\mathrm{Al}_{2} \mathrm{O}_{3}$ grain boundaries, is seen to reduce the outward transport of $\mathrm{Al}$ by about a factor of 4 . Another well-known effect of the reactive elements is that they alter the oxide grain structure from equiaxed to columnar ${ }^{108}$. The average oxide grain size is also reduced by about a factor of 1.5 to 2 .

To summarize the results discussed so far, a table is made to compare effects of Fe, $\mathrm{Ni}, \mathrm{RE}$ and $\mathrm{S}$ incorporation on oxidation rates, oxide grain sizes and the degree of $\mathrm{Al}$ outward transport, in an attempt to understand the effects of these impurities on $\mathrm{Al}$ and $\mathrm{O}$ grain boundary diffusivities. If the oxidation rate of $\mathrm{PtAl}$ is taken as a relative reference, the incorporation of $\mathrm{Fe}$ and $\mathrm{Ni}$, which increased the rate about 8-10 times, may have increased $\mathrm{D}_{\mathrm{b}}{ }^{\mathrm{Al}}$ as well as $\mathrm{D}_{\mathrm{b}}{ }^{\mathrm{O}}$. Since two-stage oxidation in ${ }^{18} \mathrm{O}_{2}$ and ${ }^{16} \mathrm{O}_{2}$ has never been done on PtAl, the relative increase of these two diffusivities cannot be estimated. The presence of $\mathrm{RE}$ in $\mathrm{Fe}$ and Ni-based alloys reduced $\mathrm{k}_{\mathrm{p}}$ as well as the oxide grain size and the amount of $\mathrm{Al}$ outward transport. Together, these results indicate a reduction in $\mathrm{D}_{\mathrm{b}}{ }^{\mathrm{Al}}$ by a factor of about 4 but with little effect on $\mathrm{D}_{\mathrm{b}}{ }^{\mathrm{O}}$. On PtAl, the reduction in $\mathrm{D}_{\mathrm{b}}{ }^{\mathrm{Al}}$ by RE may be as high as 6-8 times, which is much less than the $10^{3}$ decrease proposed by some creep studies $^{28}$. However, the present conclusion is based on very limited data, where there has been only one study on the effect of RE on the oxidation rate of PtAl, and there is no oxygen isotope studies on PtAl alloys to confirm it. The effect of sulfur is even more of an open question due to the uncertainty of whether $\mathrm{S}$ is incorporated into the $\mathrm{Al}_{2} \mathrm{O}_{3}$ scale and whether excess $\mathrm{S}$ in the alloy really affects the oxidation rate. To further complicate the topic, there may be small amounts of surface impurities, which are not treated in this paper, but may be present in the $\mathrm{Al}_{2} \mathrm{O}_{3}$ scale and affect transport rates. In order to truly understand the effect of impurities on oxidation and hence deduce from these data the effect on $\mathrm{Al}$ and $\mathrm{O}$ transport rates, one needs to start with very high purity alloys and to avoid extensive surface contamination. More studies on the kinetics and two-stage oxidation behavior of PtAl and $\mathrm{H}_{2}$-annealed Fe or Ni-based alloys should be performed. These data added to Table 5 can provide valuable information that would aid the current understanding of this subject.

\section{CONCLUDING REMARKS}

The most abundant impurities in $\mathrm{Al}_{2} \mathrm{O}_{3}$ scales that form on alloys are base metal components. They are incorporated in the growing alumina during transient stage oxidation. Depending on their size and solubility in $\mathrm{Al}_{2} \mathrm{O}_{3}$, they may segregate to grain boundaries, but the effect on transport rates seems small. Oxidation rates of Fe and Nibased alloys are on average higher than that of Pt-based by about eight to ten times. From both oxidation and creep studies, the effect of cation doping on Al boundary diffusion point to a slight increase of $\mathrm{Al}$ transport with $\mathrm{Fe}$, but a decrease with reactive elements, such as $\mathrm{Y}$ and La. Oxidation studies show that this decrease is no more than a factor of ten. $\mathrm{S}$ can be heavily segregated at the scale/alloy interface, but is not always found within the $\mathrm{Al}_{2} \mathrm{O}_{3}$ scale. Its effect on $\mathrm{Al}_{2} \mathrm{O}_{3}$ scale growth rate is not yet clear. Despite the compatible results found from oxidation and creep studies, there are still not enough data to give a clear understanding of the effect of impurities on oxidation rates or the diffusion 
rates of $\mathrm{O}$ and $\mathrm{Al}$ in $\mathrm{Al}_{2} \mathrm{O}_{3}$. This is more so for $\mathrm{O}$ than for $\mathrm{Al}$. Work that focuses on the effect of impurities should be carried out in the future. More kinetics and oxygen isotope studies are particularly needed for PtAl and high purity $\mathrm{H}_{2}$-annealed alloys, and the reactive element effect on PtAl should be further evaluated.

\section{ACKNOWLEDGMENT}

The author would like to thank Dr. Rowland Cannon of LBNL for insightful discussions throughout the course of this work.

\section{REFERENCES}

${ }^{1}$ P. Kofstad, High Temperature Corrosion, p.371-8, Elsevier Appl.. Sci. Publ., Amsterdam (1988)..

${ }^{2}$ N. Birks and G. Meier, Introduction to High Temperature Oxidation of Metals, Arnold, London, 1993.

${ }^{3}$ F. A. Kroger, "Defect Chemistry in Crystalline Solids", Ann. Rev. Mater. Sci., 7, 449-75, 1977.

${ }^{4}$ P. A. Lessing and R. S. Gordon, "Creep of Polycrystalline Alumina, Pure and Doped with Transition Metal Impurities", J. Mater. Sci., 12, 2291-2302 (1977).

${ }^{5}$ Y. Ikuma and R. S. Gordon, "Effect of Doping Simultaneously with Iron and Titanium on the Diffusional Creep of Polycrystalline $\mathrm{Al}_{2} \mathrm{O}_{3}$ ", J. Am. Ceram. Soc., 66, 13947 (1983).

${ }^{6}$ G. W. Hollenberg and R. S. Gordon, "Effect of Oxygen Partial Pressure on the Creep of Polycrystalline $\mathrm{Al}_{2} \mathrm{O}_{3}$ Doped with Cr, Fe or Ti", J. Am. Ceram. Soc., 56, 140-147 (1973).

${ }^{7}$ T. Sugita and J. A. Pask, "Creep of Doped Polycrystalline $\mathrm{Al}_{2} \mathrm{O}_{3}$ ", J. Am. Ceram. Soc., 53, 609-13 (1970).

${ }^{8}$ J. Cho, M. P. Harmer, H. M. Chan, J. M. Richman and A. M. Thompson, "Effect of Yttrium and Lanthanum on the Tensile Creep Behavior of Aluminum Oxide", J. Am. Ceram. Soc., 80, 1013-17 (1997).

${ }^{9}$ C. M. Wang, J. Cho, H. M. Chan, P. Harmer and J. M. Richman, "Influence of Dopant Concentration on Creep Properties of $\mathrm{Nd}_{2} \mathrm{O}_{3}$-Doped Alumina", J. A. Cerem. Soc., 84, 1010-16 (2001).

${ }^{10}$ V. K. Tolpygo and H. J. Grabke, "The effect of impurities on the alumina scale growth: an alternative view," Scripta Met, 38, 123-9 (1998).

11 D. Delaunay, A. M. Huntz and P. Lacombe, "Impurities influence on oxidation kinetics of Fe-Ni-Cr-Al alloys," Corr. Sci., 24, 13-25 (1984).

${ }^{12}$ D. P. Whittle and J. Stringer, "Improvements in High Temperature Oxidation Resistance by Adding of Reactive Elements or Oxide Dispersions", Phil. Trans. R. Soc. London, A295 (1980) 309. 
${ }^{13}$ K. Przybylski, A. J. Garrett-Reed, B. A. Pint, E. P. Katz and G. J. Yurek, "Segregation of $\mathrm{Y}$ to Grain Boundaries in the $\mathrm{Al}_{2} \mathrm{O}_{3}$ Scale Formed on ODS Alloy", $J$. Electrochem. Soc., 134, 3207 (1987).

${ }^{14}$ C. M. Cotell, G. J. Yurek, R. J. Hussey, D. F. Mitchell and M. J. Graham, "The Influence of Grain-Boundary Segregation of Yttrium in $\mathrm{Cr}$ sub $2 \mathrm{O}$ sub 3 on the Oxidation of Chromium Metal", Oxidation of Metals, 34, 173-200, 1990.

${ }^{15} \mathrm{P}$. Y. Hou, "Compositions at $\mathrm{Al}_{2} \mathrm{O}_{3} / \mathrm{FeCrAl}$ Interfaces after High Temperature Oxidation", Materials and Corrosion, 51, 329-337 (2000).

${ }^{16} \mathrm{P}$. Y. Hou, "Sulfur Segregation to Growing $\mathrm{Al}_{2} \mathrm{O}_{3}$ /alloy Interfaces", J. Mater. Sci. Lett., 19 (2000) 577-578.

${ }^{17}$ A. W. Funkenbusch, J. G. Smeggil and N. S. Bornstein, "Reactive ElementSulfur Interaction and Oxide Scale Adherence", Metall. Trans., 16A, 1164-1166 (1985).

${ }^{18}$ J. L. Smialek, "Effect of Sulfur Removal on $\mathrm{Al}_{2} \mathrm{O}_{3}$ Scale Adhesion", Metall. Trans. 22A, 739-752 (1991).

${ }^{19}$ G. C. Wood and T. Hodgkiess, "Mechanism of Oxidation of Dilute NickelChromium Alloys" Nature, 211 (1966) 1358-1361.

${ }^{20}$ J. P. Sauer, R. A. Rapp and J. P. Hirth, "Oxidation of Iron-ManganeseAluminum Alloys at 850 and $1000^{\circ} \mathrm{C} "$, Oxid. Metals, 18, 285-94, 1982.

${ }^{21}$ J. Jedlinski, G. Borchardt, A. Bernaski, S. Scherrer, R. Ambos and B. Rajchel, "Redistribution of Major and Minor Alloy Components in Scales Formed During Early Stages of Oxidation on FeCrAl Alloys Studied by Means of SIMS and SNMS", Microscopy of Oxidation 2, 445-454, S. B. Newcomb and M. J. Bennett eds., The Institute of Metals, 1993.

${ }^{22}$ W. J. Quaddakkers, A. Elschner, W. Speier and H. Nickel, "Composition and Growth Mechanisms of Alumina Scales on FeCrAl-based Alloys Determined by SNMS", Appl. Surf. Sci., 52, 271-87 (1991).

${ }^{23}$ J. L. Smialek and R. Gibala, "Structure of Transient Oxides Formed on NiCrAl Alloys", Metall. Trans. A, 14A, 2143-2161, 1983.

${ }^{24}$ J. L. Smialek, J. Doychak and D. J. Gaydosh, "Oxidation Behavior of FeAl + Hf, Zr, B", Oxidation of Metals, 34, 259-275, 1990.

${ }^{25}$ P. Y. Hou, X. F. Zhang and R. M. Cannon, "Impurity Distribution in $\mathrm{Al}_{2} \mathrm{O}_{3}$ formed on FeCrAl Alloy", paper submitted to Scripta Met.

${ }^{26}$ P. Y. Hou and X. F. Zhang, unpublished results.

${ }^{27}$ Phase Diagram for Ceramists, Fig. 309, E. M. Levin, C. R. Robbins and H. F. McMurdie, The Am. Ceramic Soc. Inc., 1964.

${ }^{28}$ M. P. Harmer, "Additives, Sintering and Creep of Alumina Ceramics", paper presented at the International Sym. on Science and Technology of Alumina, Schloss Rinberg, Germany, March 17-22, 2002. 
${ }^{29}$ A. Muan, "On the Stability of the Phase $\mathrm{Fe}_{2} \mathrm{O}_{3}-\mathrm{Al}_{2} \mathrm{O}_{3}$ ", Am. J. Sci., 256, 413-22 (1958).

${ }^{30}$ I. A. Novokhatskii, B. F. Velov, A. V. Gorokh and A. A. Savinskaya, "The Phases Diagram for the System Ferrous-Oxide-Alumina", Russ. J. Phys. Chem., 39, 1498-9 (1965).

${ }^{31}$ E. C. Dickey, B. A. Pint, K. B. Alexander and I. G. Wright, "Oxidation Behavior of Platinum-Aluminum Alloys and the Effect of Zr-Doping," Journal of Materials Research, 14, 4531-40 (1999).

${ }^{32}$ D. P. Whittle and H. Hindam, "Microstructure and Growth of Protective $\mathrm{Cr}_{2} \mathrm{O}_{3}$ and $\mathrm{Al}_{2} \mathrm{O}_{3}$ Scales at High Temperature", Oxid. Metals, 18, 245-62 (1982).

${ }^{33}$ I. G. Wright, B. A. Pint and P. F. Tortorelli, "High Temperature Oxidation Behavior of ODS-Fe ${ }_{3} \mathrm{Al}$ ", Oxid. Metals, 55, 333-37, 2001.

${ }^{34}$ B. A. Pint, K. L. More, P. F. Tortorelli, W. D. Porter and I. G. Wright, "Optimizing the Imperfect Oxidation Performance of Iron Aluminides", Materials Science Forum, 369-372, 411-418, 2001

${ }^{35}$ B. A. Pint, A. J. Garratt-Reed and L. W. Hobbs, "The Effect of a Zr Alloy Addition on the Oxidation Behavior of $\beta-\mathrm{NiAl}$ : The Transition from Benefit to Breakdown", Microscopy of Oxidation II, $2^{\text {nd }}$ International Conference on Microscopy of Oxidation, Selwyn College, University of Cambridge, UK, March 29-31, 1993, ed. S. B. Newcomb and M. J. Bennett, pp. 463-475, The Institute of Materials, 1993.

${ }^{36}$ B. A. Pint and L. W. Hobbs, "The Oxidation Behavior of $\mathrm{Y}_{2} \mathrm{O}_{3}$-Dispersed $\mathrm{Ni}_{3} \mathrm{Al}$ ", Proc. Oxide Films on Metals and Alloys, Toronto, Canada, 1992, The Electrochemical Society, Inc. (USA), pp. 92-100, 1992.

${ }^{37}$ B. A. Pint and L. W. Hobbs, "The Formation of $\alpha-\mathrm{Al}_{2} \mathrm{O}_{3}$ Scales at $1500^{\circ} \mathrm{C}$ ", Oxid. Met., 41, 203-233, 1994.

${ }^{38}$ B. A. Pint, A. J. Garratt-Reed and L. W. Hobbs, "The Effect of Y and Ti on FeCrAl Oxidation at $1400^{\circ} \mathrm{C} "$, J. de Physique IV, C9-3, 247-56, 1993.

${ }^{39}$ B. A. Pint and K. B. Alexander, "Grain Boundary Segregation of Cation Dopants in $\alpha-\mathrm{Al}_{2} \mathrm{O}_{3}$ Scales", J. Electrochem. Soc., 145, 1819-29, 1998.

40 J. S. Sheasby, and D. B. Jory, "Electrical Properties of Growing Alumina Scales", Oxid. Met., 12, 527-539, 1978.

${ }^{41}$ E. J. Felten and F. S. Pettit, "Development, Growth and Adhesion of $\mathrm{Al}_{2} \mathrm{O}_{3}$ on Pt-Al Alloys", Oxid. Met., 10, 189-223, 1976.

${ }^{42}$ C. S. Giggins and F. S. Pettit, "Oxidation of Ni-Cr-Al Alloys Between 1000 and $1200^{\circ} \mathrm{C} "$, J Electrochem Soc, 118, 1782-1790, 1971.

${ }^{43}$ J. K. Tien and F. S. Pettit, "Mechanism of Oxide Adherence on Fe-25Cr-4Al Yt or Sc Alloy", Metall Trans, 3, 1587-1599, 1972. 
${ }^{44}$ F. S. Pettit, "Oxidation Mechanisms for Ni-Al Alloys at Temperatures Between 900 And $1300^{\circ} \mathrm{C}^{\prime}$, AIME Met Soc Trans, 239, 1296-1305, 1967.

${ }^{45}$ M. S. Stasik, F. S. Pettit, G. H. Meier, A. Ashary and J. L. Smialek, "Effects of reactive element additions and sulphur removal on the oxidation behavior of $\mathrm{FeCrAl}$ alloys", Scr. Metall. Mater., 31, 1645-1650, 1994.

${ }^{46}$ C. Sarioglu, M. J. Stiger, J. R. Blachere, R. Janakiraman, E. Schumann, A. Ashary, F. S. Pettit and G. H. Meier, "The adhesion of alumina films to metallic alloys and coatings", Materials and Corrosion,51, 358-72, 2000.

${ }^{47}$ H. M. Hindam and W. W. Smeltzer, "Growth and Microstructure of $\alpha-\mathrm{Al}_{2} \mathrm{O}_{3}$ on Ni--Al Alloys: Internal Precipitation and Transition to External Scale", J. Electrochem. Soc., 127, 1622-1630, 1980.

${ }^{48}$ J. L. Smialek, "Oxide Morphology and Spalling Model for NiAl", Metall. Trans. A, 9A, 309-320, 1978.

${ }^{49}$ J. L. Smialek and R. Gibala, "Diffusion Processes in $\mathrm{Al}_{2} \mathrm{O}_{3}$ Scales, in High Temperature Corrosion, pp. 274-83, R. A. Rapp ed., NACE, Houston, TX (1981).

${ }^{50}$ M. Nanko, M. Ozawa and T. Maruyama "Internal and external oxidation of $\mathrm{Pt}(\mathrm{Al})$ solid solution at elevated temperatures", J. Electrochemical Soc., 147, 283-288, 2000.

${ }^{51}$ C. H. Xu, W. Gao and H. Gong, "Oxidation behaviour of FeAl intermetallics, the effects of $\mathrm{Y}$ and/or $\mathrm{Zr}$ on isothermal oxidation kinetics", Intermetallics, 8, 769-79, 2000.

52 J. D. Kuenzly and D. L. Douglass, "Oxidation Mechanism of $\mathrm{Ni}_{3} \mathrm{Al}$ Containing Yt", Oxid. Met., 6, 139-178, 1974.

${ }^{53}$ A. Kumar, M. Nasrallah and D. L. Douglass, "Effect of Yt and Th on the Oxidation Behaviour of Ni-Cr-Al Alloys". Oxid. Met., 8, 227-263, 1974.

${ }^{54}$ F. A. Golightly, F. H. Stott and G. C. Wood, "The Relationship Between Oxide Grain Morphology and Growth Mechanisms for FeCrAl and FeCrAlY Alloys" $J$. Electrochem. Soc., 126, 1035-1042, 1979.

${ }^{55}$ A. S. Kahn, C. E. Lowell and C. A. Barreett, "The Effect of Zirconium on the Isothermal Oxidation of Nominal Ni-14Cr-24Al Alloys", J. Electrochem Soc., 127, 670-9, 1980.

${ }^{56}$ D. Nicolas-Chaubet, C. Haut, C. Picard, F. Millot and A. M. Huntz, "Linear Weight Gain and Parabolic Oxide Thickness Variations vs. Oxidation Time: the Signature of Diffusion Along Two Dimensions in $\mathrm{Al}_{2} \mathrm{O}_{3}$ Scale Formed on $\beta$-NiAl", Mater. Sci. Eng. A, A120-A121, 83-89, 1989.

${ }^{57}$ T. Amano, S. Yajima and Y. Saito, "High-Temperature Oxidation Behavior of Fe--20Cr--4Al Alloys with Small Additions of Cerium", Trans. Jpn. Inst. Met., 20, 431$441,1979$.

${ }^{58}$ T. Amano, S. Yajima and Y. Saito, "High Temperature Oxidation of Ni--20Cr-5Al Alloys With Small Additions of Cerium", Trans. Jpn. Inst. Met., 26, 433-443, 1985. 
${ }^{59}$ P. Y. Hou, R. M. Cannon, H. Zhang and R. L. Williamson, Interface Convolution and Its Effect on Alumina Scale Spallation, ECS fall meeting, San Antonio, TX, Oct. 6-11, 1996, in "Fundamental Aspects of High Temperature Corrosion", ed. D. A. Shores, R. A. Rapp and P. Y. Hou, pp. 28-40, ECS Proceedings, Vol 96-26, Electrochem. Soc., Pennington, PA, 1997.

${ }^{60}$ V. K. Tolpygo and D. R. Clarke, "Wrinkling of $\alpha-\mathrm{Al}_{2} \mathrm{O}_{3}$ Films Grown by Thermal Oxidation - I. Quantitative Studies on Single Crystals of FeCrAl Alloy", Acta mater., 46, 5135-66, 1998.

${ }^{61}$ P. Y. Hou, "Kinetics of Sulfur Segregation to Scale-Alloy Interfaces", in "High Temperature Corrosion and Materials Chemistry", ed. P. Y. Hou, M. J. McNallan, R. Oltra, E. J. Opila and D. A. Shores, pp. 198-210, the Electrochem. Soc., 1998

${ }^{62}$ P. Y. Hou, "Impurity Segregation to Scale/Alloy Interfaces and Its Effect on Interfacial Properties", Materials Science Forum, 369-372, 23-38, 2001.

${ }^{63} \mathrm{P}$. Y. Hou and John Moskito, "Sulfur Distribution on $\mathrm{Al}_{2} \mathrm{O}_{3} / \mathrm{FeAl}$ Interfaces Studied by Field Emission-Auger Electron Spectroscopy", submitted to Oxidation of Metals.

${ }^{64}$ Peggy Y. Hou and John Stringer, "Oxide Scale Adhesion and Impurity Segregation at the Scale/Metal Interface", Oxid. Met., 38, 323-345, 1992.

${ }^{65}$ P. Y. Hou and G. D. Ackerman, "Chemical State of Segregants at $\mathrm{Al}_{2} \mathrm{O}_{3} / \mathrm{Alloy}$ Interfaces Studied using $\mu X P S "$, Applied Surface Science, 178, 156-164, 2001.

${ }^{66} \mathrm{~J}$. Doychak and M. Rühle, "TEM Studies of Oxidized NiAl and $\mathrm{Ni}_{3} \mathrm{Al}$ Cross Sections", Oxid. Met., 31, 431-52, 1989.

${ }^{67}$ S. Taniguchi, T. Shibata and A. Andoh, "Phase transformation of alumina scales formed on Al-deposited stainless steel foils", Proc. International Conference on MetalSupported Automotive Catalytic Converters (MACC'97), ed. H. Bode., pp. 179-189, 1997.

${ }^{68}$ J. C. Yang, K. Nadarzinski, E. Schumann and M. Rühle, "Electron microscopy studies of $\mathrm{NiAl} / \gamma-\mathrm{Al}_{2} \mathrm{O}_{3}$ interfaces," Scripta Met, 33, 1043-8, 1995.

${ }^{69}$ P. Tomaszewicz and G. R. Wallwork, "Iron-Aluminum Alloys: A Review of Their oxidation Behavior", Rev. High Temp. Mater. 4, 75-105, 1978.

${ }^{70}$ D. Renusch, M. Grimsditch, I. Koshelev, B. W. Veal, and P. Y. Hou, "Strain Determination in Thermally Grown Alumina Scales Using Fluorescence Spectroscopy", Oxid. Metals, 48, 471-495, 1997.

${ }^{71}$ R. W. Balluffi, "Grain Boundary Structure and Segregation", in Interfacial Segregation, pp. 193-237, ed. W. C. Johnson and J. M. Blakely, ASM 1977.

${ }^{72}$ P. Lejcek, A. V. Krajnikov, Yu.N. Ivashchenko and J. Adamek, "Anisotropy of Interfacial Segregation: Grain Boundaries and Free Surfaces", Surf. Sci., 269/270, $1147-$ $1151,1992$.

73 J. D. Rittner and D. N. Seidman, "Solute-atom Segregation to $<110>$ symmetric tilt grain boundaries", Acta mater., 45, 3191-3202, 1997. 
${ }^{74}$ G. Ben Abderrazik, G. Moulin, A. M. Huntz and R. Berneron, "Influence of impurities, such as carbon and sulfur, on the high temperature oxidation behavior of $\mathrm{Fe}_{72} \mathrm{Cr}_{23} \mathrm{Al}_{5}$ alloys," J. Mater. Sci., 19, 3173-84 (1984).

${ }^{75}$ P. Fox, D. G. Lees and G. W. Lorimer, "Sulfur Segregation During the HighTemperature Oxidation of Chromium", Oxid. Metals, 36, 491-503 (1991).

${ }^{76}$ D. G. Lees, "On the Reasons for the Effects of Dispersions of Stable Oxides and Additions of Reactive Elements on the Adhesion and Growth-Mechanisms of Chromia and Alumina Scales - The Sulfur Effect", Oxid. Met., 27 75-91 (1987).

${ }^{77}$ P. Y. Hou and J. L. Smialek, "The Effect of $\mathrm{H}_{2}$-Anneal on the Adhesion of $\mathrm{Al}_{2} \mathrm{O}_{3}$ Scales on a Fe ${ }_{3}$ Al-based Alloy", Mater. at High Temp., 17, 79-85, 2000.

${ }^{78}$ H. Al-Badairy, G. J. Tatlock and J. Le Coze, "An Auger Study of Thermally Spalled Oxides on Fe-20Cr-5Al Based Alloys", Third International Conference on the Microscopy of Oxidation, Sept. 16-18, 1996, Cambridge, UK, in Microscopy of Oxidation 3, ed. S. B. Newcomb and J. A. Little, p. 105-114, The Institute of Materials, 1997.

${ }^{79}$ G. M. Meier, F. S. Pettit and J. L. Smialek, "The Effects of Reactive Element Additions and Sulphur Removal on the Adherence of Alumina to Nickel- and Iron-Base Alloys", Werkstoffe und Korrosion, 46, 232-240, 1995.

${ }^{80}$ T. Amano, A. Hara, N. Sakai and K Sasaki, "High Temperature Oxidation of Fe20Cr-4Al Alloys with Small Amounts of Sulfur at 1273-1673 K", 14th International Corrosion Congress (ICC), Cape Town, South Africa, 26 Sept.-1 Oct. 1999, p. 9, Corrosion Institute of Southern Africa, 1999.

${ }^{81}$ K. Prussner, E. Schumann and M. Ruhle, "Oxidation of S-Doped $\beta-N i A 1$ in $\mathrm{H}_{2} / \mathrm{H}_{2} \mathrm{O}$ and in Air, ECS Fall Meeting, San Antonio, TX, Oct. 6-11, 1996, in Fundamental Aspects of High Temperature Corrosion, ed. D. A. Shores, R. A. Rapp and P. Y. Hou, pp. 344-351, Proc. Vol. 96-26, The Electrochemical Society, Inc., 1997.

${ }^{82}$ A. S. Khanna, C. Wasserfuhr, W. J. Quadakkers and H. Nickel, "Addition of Yttrium, Cerium and Hafnium to Combat the Deleterious Effect of Sulphur Impurity during Oxidation of an Ni-Cr-Al Alloy", Mater. Sci. Eng., A120, 185-191 (1989).

${ }^{83}$ E. Schumann, J. C. Yang, M. J. Graham and M. Rühle, "Segregation Studies of Oxidized Y and Zr Doped NiAl", Werk. und Korro., 46, 218 (1995).

${ }^{84}$ K. Ishii, M. Kohno, S. Ishikawa and S. Satoh, "Effect of rare-earth elements on high-temperature oxidation resistance of Fe-20Cr-5Al alloy foils", Materials Transactions, JIM (Japan), 38, 787-792, 1997.

${ }^{85}$ C. Mennicke, E. Schumann, J. Le Coze, J. L. Smialek, G. H. Meier and M. Ruhle, "SEM- and TEM-studies of the oxidation of FeCrAl", Microscopy of Oxidation--3, Cambridge, UK, Sept. 16-18, 1996, ed. S. B. Newcomb and J. A. Little, Institute of Materials (UK), 95-104, 1997.

${ }^{86}$ K. B. Alexander, K. Prüßner, P. Y. Hou and P. F. Tortorelli, "Microstructure of Alumina Scales and Coatings on Zr-containing Iron Aluminide Alloys", Microscopy of Oxidation 3, 246-255, J. B. Newcomb and J. A. Little eds., The Institute of Metals, 1997. 
${ }^{87}$ T. A. Ramanarayanan, M. Raghavan and R. Petkovic-Luton, "Metallic Yttrium Additions to High-Temperature Alloys: Influence on $\mathrm{Al}_{2} \mathrm{O}_{3}$ Scale Properties", Oxid. Met., 22, 83-100, 1984.

${ }^{88}$ B. A. Pint, A. J. Garratt-Reed and L. W. Hobbs, "The reactive element effect in commercial ODS FeCrAl alloys", Materials at High Temperatures, 13, 3-16, 1995.

${ }^{89}$ R. A. Versaci, D. Clemens, W. J. Quadakkers and R. Hussey, "Distribution and Transport of Yttrium in Alumina Scales on Iron-Base ODS Alloys", Solid State Ionics,. 59, 235-242, 1993.

${ }^{90}$ B. A. Pint, I. G. Wright, IG, W. Y. Lee, Y. Zhang, K. Prussner and K. B. Alexander, "Substrate and bond coat compositions: factors affecting alumina scale adhesion", Mat. Sci. and Eng. A, 245, 201-211, 1998.

${ }^{91}$ E. Schumann, J. C. Yang, M. Ruhle and M. J. Graham, "High resolution SIMS and analytical TEM evaluation of alumina scales on beta -NiAl containing zirconium or yttrium", Oxidation of Metals, 46, 37-49, 1996.

92 J. Stringer and P. Y. Hou, "A Comparison of the Effect of Reactive Metal Alloy Additions, Oxide Dispersions, Ion-implantation and Surface Oxide Coats on High Temperature Oxidation", Proc. Symp. on Corrosion and Particle Erosions at High Temperatures, ed. V. Srinivasan and K. Vedula, 383-401, TMS Annual Meeting, Las Vegas, NV., Feb. 27-Mar. 3, 1989.

${ }^{93}$ B. A. Pint "The oxidation behavior of oxide-dispersed beta -NiAl. I. Short-term performance at $1200^{\circ} \mathrm{C} "$, Oxidation of Metals, 49, 531-559, 1998.

${ }^{94}$ R. M. Cannon and R. L. Coble, "Review of Diffusional Creep of $\mathrm{Al}_{2} \mathrm{O}_{3}$ " in Deformation of Ceramic Materials, ed. R. C. Bradt \& R. E. Tressler, Plenum Press, N.Y., p. 61 (1975).

${ }^{95}$ R. M. Cannon and P. Y. Hou, " Diffusion Induced Stress Generation During Oxidation", in "High Temperature Corrosion and Materials Chemistry", ed. P. Y. Hou, M. J. McNallan, R. Oltra, E. J. Opila and D. A. Shores, pp. 594-607, the Electrochem. Soc., 1998.

${ }^{96}$ A. Mocellin and W. D. Kingery, "Creep Deformation in MgO Saturated Large Grain Size $\mathrm{Al}_{2} \mathrm{O}_{3}$ ", J. Am. Ceram. Soc., 54, 339, 1971.

${ }^{97}$ H. M. Hindam and W. W. Smeltzer, "Application of Auger Electron Spectroscopy and Inert Metal Marker Techniques to Determine Metal and Oxygen Transport in Oxide Films on Metals", Oxid. Met., 14, 337-349, 1980.

${ }^{98}$ Y. Oishi and W. D. Kingery, "Self-Diffusion of Oxygen in Single-Crystal and Polycrystalline Aluminum Oxide", J. Chem. Phys., 33, 480-86 (1960).

${ }^{99}$ E. W. A. Young and J. H. W. De Wit, "The Use of a exp 18 O Tracer and Rutherford Backscattering Spectrometry to Study the Oxidation Mechanism of NiAl", Solid State Ionics, 16, 39-46, 1985. 
${ }^{100}$ K. P. R. Reddy, J. L. Smialek and A. R. Cooper, "Oxygen-18 Tracer Studies of $\mathrm{Al}_{2} \mathrm{O}_{3}$ Scale Formation on NiCrAl Alloys", Oxid. Met., 17, 429-49, 1982.

${ }^{101}$ J. Jedlinski and G. Borchardt, "On the Oxidation Mechanism of Alumina Formers", Oxid. Met., 36, 317-37, 1991.

${ }^{102}$ W. J. Quadakkers, A. Elschner, W. Speier and H. Nickel, "Composition and Growth Mechanisms of Alumina Scales on FeCrAl-based Alloys Determined by SNMS", Appl. Surf. Scie., 52, 271-87, 1991.

${ }^{103}$ R. Prescott, D. F. Mitchell, G. I. Sproule and M. J. Graham, "Transport in $\alpha-$ $\mathrm{Al}_{2} \mathrm{O}_{3}$ Scales on Fe-Al and Ni-Al Alloys at $1100^{\circ} \mathrm{C}^{\prime}$, Solid State Ionics, 53-56, 229-237, 1992.

${ }^{104}$ B. A. Pint, J. R. Martin and L. W. Hobbs, "Exp 18 O/SIMS Characterization of the Growth Mechanism of Doped and Undoped $\alpha-\mathrm{Al}_{2} \mathrm{O}_{3}$ ", Oxid. Met., 39, 167-95, 1993.

${ }^{105}$ C. Mennicke, E. Schumann, M. Ruhle, R. J. Hussey, G. I. Sproule and M. J. Graham, "The effect of yttrium on the growth process and microstructure of $\alpha-\mathrm{Al}_{2} \mathrm{O}_{3}$ on FeCrAl" Oxid. Metals, 49, 455-466 (1998).

${ }^{106}$ S. N. Basu and J. W. Halloran, "Tracer isotope Distribution in Growing Oxide Scales", Oxid. Met., 27, 143-55, 1987.

${ }^{107}$ A. Atkinson, R. I. Taylor and P. D. Goode, "Transport processes in the Oxidation of Ni Studied Using Tracers in Growing NiO Scales", Oxid. Met., 13, 519-43, 1979.

${ }^{108}$ B. A. Pint, "The morphology of Al sub $2 \mathrm{O}$ sub 3 scales: indicators of phase, growth mechanisms, and grain boundary segregation", in "Fundamental Aspects of High Temperature Corrosion", ed. D. A. Shores, R. A. Rapp and P. Y. Hou, pp. 74-85, ECS Proceedings, Vol 96-26., Electrochem. Soc., Pennington, PA, 1997. 
Table 1: Sulfur Distribution in Alumina Scale and Its Effect on Scale Growth

\begin{tabular}{|c|c|c|c|c|}
\hline $\begin{array}{c}\text { Alloy and } \\
\text { Sulfur Content }\end{array}$ & $\begin{array}{l}\text { Oxidation } \\
\text { Condition }\end{array}$ & Sulfur in $\mathrm{Al}_{2} \mathrm{O}_{3}$ & $\begin{array}{c}\text { Effect on } \\
\mathrm{Al}_{2} \mathrm{O}_{3} \text { Growth }\end{array}$ & Reference \\
\hline $\begin{array}{c}\mathrm{Fe}_{3} \mathrm{Al} \\
(24 \mathrm{ppm})\end{array}$ & $1000^{\circ} \mathrm{C}, 24 \mathrm{~h}, \mathrm{O}_{2}$ & $\begin{array}{l}\text { not detected } \\
\text { (TEM) }\end{array}$ & & Hou et $\mathrm{al}^{26}$ \\
\hline $\begin{array}{c}\mathrm{Fe}_{3} \mathrm{Al} \\
\left(\mathrm{H}_{2} \text {-annealed }\right)\end{array}$ & $1000^{\circ} \mathrm{C}, 24 \mathrm{~h}, \mathrm{O}_{2}$ & --- & reduced $\mathrm{k}_{\mathrm{p}} \mathrm{x} 2$ & $\begin{array}{c}\text { Hou \& } \\
\text { Smialek }^{77}\end{array}$ \\
\hline $\begin{array}{c}\text { FeCrAl } \\
(32 \mathrm{ppm})\end{array}$ & $\begin{array}{c}1000-1200^{\circ} \mathrm{C} \\
3 \mathrm{~m}-120 \mathrm{~h}\end{array}$ & $\begin{array}{c}\text { only on void } \\
\text { surfaces (TEM) }\end{array}$ & & Hou et $\mathrm{al}^{25}$ \\
\hline $\begin{array}{c}\text { FeCrAl } \\
(45 \mathrm{ppm})\end{array}$ & $1060^{\circ} \mathrm{C}, 24 \mathrm{~h}$ & $\begin{array}{l}\text { not detected } \\
\text { (TEM) }\end{array}$ & & $\underset{\mathrm{al}^{78}}{\text { Al-Badairy et }}$ \\
\hline $\begin{array}{c}\text { FeCrAl } \\
\left(\mathrm{H}_{2} \text {-annealed }\right)\end{array}$ & $1100^{\circ} \mathrm{C}, 160 \mathrm{~h}$ & --- & no effect & Meier et $\mathrm{al}^{79}$ \\
\hline $\begin{array}{c}\mathrm{FeCrAl} \\
(3-1300 \mathrm{ppm})\end{array}$ & $\begin{array}{c}1100^{\circ} \mathrm{C}, 100 \mathrm{~h}, \\
\text { air }\end{array}$ & --- & no effect & Amano et $\mathrm{al}^{80}$ \\
\hline $\begin{array}{c}\mathrm{NiAl} \\
(270 \mathrm{ppm})\end{array}$ & $\begin{array}{c}950^{\circ} \mathrm{C}, \mathrm{H}_{2} / \mathrm{H}_{2} \mathrm{O} \\
\text { air, } 50 \mathrm{~h}\end{array}$ & $\begin{array}{c}\text { at grain } \\
\text { boundary (TEM) }\end{array}$ & $\begin{array}{l}\text { increased } \\
\text { scale } \\
\text { thickness x2 }\end{array}$ & Pru $\beta$ ner et al ${ }^{81}$ \\
\hline $\begin{array}{c}\text { NiCrAl } \\
(100-200 \mathrm{ppm})\end{array}$ & $\begin{array}{c}1000^{\circ} \mathrm{C}, \text { cyclic } \\
\text { air }\end{array}$ & in scale (EDS) & increased rate & Khanna et $\mathrm{al}^{82}$ \\
\hline
\end{tabular}


Table 2: Reactive Element Segregation at $\mathrm{Al}_{2} \mathrm{O}_{3}$ Grain Boundaries Detected by Analytical TEM

\begin{tabular}{|c|c|c|}
\hline Segregant & Alloy & Reference \\
\hline $\mathrm{Zr}$ & $\mathrm{NiAl}+\mathrm{Zr}$ & $\begin{array}{l}\text { Pint et al }{ }^{35} ; \text { Schumann et } \\
\mathrm{al}^{83}\end{array}$ \\
\hline $\mathrm{Y}$ & $\mathrm{NiAl}+\mathrm{Y}$ & Schumann et al ${ }^{83}$ \\
\hline $\mathrm{Y}$ & $\mathrm{Ni}_{3} \mathrm{Al}+\mathrm{Y}_{2} \mathrm{O}_{3}$ & Pint and Hobbs ${ }^{37}$ \\
\hline $\mathrm{La}, \mathrm{Zr}$ & $\mathrm{FeCrAl}+\mathrm{La},+\mathrm{La}, \mathrm{Zr},+\mathrm{La}, \mathrm{Ti}$ & Ishii et $\mathrm{al}^{84}$ \\
\hline $\mathrm{Y}$ & $\mathrm{FeCrAl}+\mathrm{Y}$ & Mennicke et al ${ }^{85}$ \\
\hline $\mathrm{Zr}$ & $\mathrm{Fe}_{3} \mathrm{Al}+\mathrm{Zr}$ & Alexander et al ${ }^{86}$ \\
\hline $\mathrm{Zr}$ & $\mathrm{PtAl}+\mathrm{Zr}$ & Dickey et $\mathrm{al}^{31}$ \\
\hline $\mathrm{Y}$ & \multirow[t]{2}{*}{ MA956 (Fe-based $\left.+\mathrm{Y}_{2} \mathrm{O}_{3}, 0.3 \mathrm{Ti}\right)$} & Ramanarayanan et al ${ }^{87}$ \\
\hline $\mathrm{Y}, \mathrm{Ti}$ & & $\begin{array}{l}\text { Przybylski et al }{ }^{13} \text {; Versaci } \\
\text { et al }^{99} ; \text { Pint et } \mathrm{al}^{88}\end{array}$ \\
\hline $\mathrm{Zr}$ & $\begin{array}{l}\text { Kanthal APM (Fe-based }+\mathrm{ZrO}_{2} \text {, } \\
0.03 \mathrm{Ti})\end{array}$ & Pint et a ${ }^{88}$ \\
\hline $\mathrm{Ta}, \mathrm{Y}, \mathrm{Hf}, \mathrm{Zr}$ & Rene N5 (Ni-based super alloy) & Pint et $\mathrm{al}^{90}$ \\
\hline
\end{tabular}


Table 3: Effect of Reactive Element Addition on Oxidation Rates

\begin{tabular}{|c|c|c|c|c|c|}
\hline $\begin{array}{l}\text { Alloy } \\
\text { System }\end{array}$ & $\begin{array}{l}\text { Oxidation } \\
\text { Condition }\end{array}$ & Rate w/o RE & RE Type & Rate w/ RE & Ref. \\
\hline $\mathrm{NiAl}$ & \multirow[t]{6}{*}{$1200^{\circ} \mathrm{C}$} & $(1.4 \pm 0.4) \times 10^{-11}$ & Ti, La, Zr, Hf, Y & $(8.0 \pm 4.1) \times 10^{-12}$ & \multirow{5}{*}{$\begin{array}{l}35,36, \\
33,39, \\
31\end{array}$} \\
\hline $\mathrm{Ni}_{3} \mathrm{Al}$ & & $7.1 \times 10^{-12}$ & $Y$ & $(4.3 \pm 3.1) \times 10^{-12}$ & \\
\hline $\mathrm{Fe}_{3} \mathrm{Al}$ & & $(1.3 \pm 0.2) \times 10^{-11}$ & $\mathrm{Hf}, \mathrm{Zr}, \mathrm{Y}$ & $(4.9 \pm 2.4) \times 10^{-12}$ & \\
\hline $\mathrm{FeCrAl}$ & & $(1.8 \pm 0.6) \times 10^{-11}$ & $\begin{array}{c}\mathrm{Nb}, \mathrm{Ti}, \mathrm{Sc}, \mathrm{Hf} \\
\mathrm{Gd}, \mathrm{Ba}, \mathrm{Nd}, \mathrm{La}, \\
\mathrm{Zr}, \mathrm{Y}\end{array}$ & $(7.1 \pm 2.8) \times 10^{-12}$ & \\
\hline PtAl & & $(1.6 \pm 0.4) \times 10^{-11}$ & $\mathrm{Zr}$ & $4.1 \times 10^{-12}$ & \\
\hline $\mathrm{FeCrAl}$ & & $7.8 \times 10^{-12}$ & Y & $4.1 \times 10^{-12}$ & 43 \\
\hline $\mathrm{FeCrAl}$ & $1150^{\circ} \mathrm{C}$ & $8.5 \times 10^{-12}$ & $\mathrm{Ti}$ & $2 \times 10^{-13}$ & \multirow[t]{2}{*}{46} \\
\hline NiCrAl & $1100^{\circ} \mathrm{C}$ & $1.1 \times 10^{-12}$ & $\mathrm{Y}, \mathrm{Hf}$ & $(4.5 \pm 2.1) \times 10^{-13}$ & \\
\hline
\end{tabular}


Table 4: Summary of Oxygen Isotope Experiments

\begin{tabular}{|c|c|c|c|c|}
\hline \multirow{2}{*}{$\begin{array}{l}\text { Alloy and } \\
\text { oxidation }\end{array}$} & \multirow{2}{*}{$\begin{array}{l}180 \text { detection } \\
\text { technique }\end{array}$} & \multicolumn{2}{|c|}{$\%$ of outward growth } & \multirow[t]{2}{*}{ Reference } \\
\hline & & without RE & with RE & \\
\hline $\mathrm{FeCrAl}, 900^{\circ} \mathrm{C}$ & \multirow[t]{3}{*}{ SNMS } & 50.39 & 12.91 & \multirow{3}{*}{$\begin{array}{l}\text { Quakakkers et } \\
\mathrm{al}^{102}\end{array}$} \\
\hline $1000^{\circ} \mathrm{C}$ & & 46.51 & 15.58 & \\
\hline $1100^{\circ} \mathrm{C}$ & & 55.02 & 23.55 & \\
\hline $\mathrm{NiAl}, 1200^{\circ} \mathrm{C}$ & \multirow[t]{2}{*}{ SIMS } & $\begin{array}{l}48.80 \\
50.61\end{array}$ & $\begin{array}{l}9.53 \\
5.52\end{array}$ & \multirow[t]{2}{*}{ Pint et $\mathrm{al}^{104}$} \\
\hline $\mathrm{FeCrAl}, 1200^{\circ} \mathrm{C}$ & & 54.76 & 6.81 & \\
\hline $\mathrm{NiCrAl}, 1100^{\circ} \mathrm{C}$ & $\begin{array}{c}\text { proton } \\
\text { activation }\end{array}$ & & 14.75 & Reddy et a $1^{100}$ \\
\hline
\end{tabular}

average: $\quad 51.02 \pm 3.05 \quad 12.66 \pm 6.14$ 
Teble 5: Possible Conclusions on Al and O Diffusivities Deduced from Impurity Effects on $\mathrm{Al}_{2} \mathrm{O}_{3}$ Scale Growth.

\begin{tabular}{|c|c|c|c|c|}
\hline \multirow[b]{2}{*}{ Comparisons } & \multicolumn{3}{|c|}{ Effects on } & \multirow[b]{2}{*}{ Inference } \\
\hline & $\mathrm{k}_{\mathrm{p}}$ & $\begin{array}{c}\text { grain } \\
\text { size }\end{array}$ & $\begin{array}{l}\text { outward } \\
\text { transport }\end{array}$ & \\
\hline $\mathrm{Fe}$, Ni-based vs PtAl & up $8-10 x$ & same & -- & $\begin{array}{l}\mathrm{Fe} \text { and } \mathrm{Ni} \text { increase } \mathrm{D}_{\mathrm{b}}{ }^{\mathrm{Al}} \\
\text { and/or } \mathrm{D}_{\mathrm{b}}{ }^{\mathrm{O}} \text { by max.10x }\end{array}$ \\
\hline $\mathrm{Fe}, \mathrm{Ni}$-based with RE vs. w/o & down $2 x$ & $\begin{array}{l}\text { down } \\
1.5-2 \mathrm{x}\end{array}$ & down $4 x$ & $\begin{array}{l}\text { RE reduces } D_{b}{ }^{A l} \text { by } 4 x \text {, has } \\
\text { little effect on } D_{b}{ }^{O}\end{array}$ \\
\hline Pt-based with RE vs. w/o & down $4 x$ & $\begin{array}{l}\text { down } \\
1.5-2 \mathrm{x}\end{array}$ & -- & $\begin{array}{l}\text { If } \mathrm{RE} \text { has little effect on } \\
\mathrm{D}_{\mathrm{b}}{ }^{\mathrm{C}} \text {, it reduces } \mathrm{D}_{\mathrm{b}}{ }^{\mathrm{Al}} \text { by } 6- \\
8 \mathrm{x}\end{array}$ \\
\hline S from alloys & down $2 x$ & same & -- & $\begin{array}{l}\text { Effects on } \mathrm{D}_{\mathrm{b}}{ }^{\mathrm{Al}} \text { and } \mathrm{D}_{\mathrm{b}}{ }^{\mathrm{O}} \\
\text { small }\end{array}$ \\
\hline
\end{tabular}




\section{FIGURE CAPTIONS}

Figure 1: Auger depth profiles showing the composition of oxides on a FeCrAl alloy oxidized for different times in a $1000^{\circ} \mathrm{C}$ furnace in $\mathrm{O}_{2}$. (a) Initial surface before oxidation, (b) after $1 \mathrm{~min}$, specimen surface temperature, $\mathrm{T}$, at $670^{\circ} \mathrm{C}$, (c) after $3 \mathrm{~min}, \mathrm{~T}=970^{\circ} \mathrm{C}$ and (d) after $11 \mathrm{~min}, \mathrm{~T}=1000^{\circ} \mathrm{C}$.

Figure 2: Concentration changes of different components in the oxide scale with time, determined by integrating the oxide portion of the depth profile curves shown in Fig. 1.

Figure 3: Parabolic rate constants from references 31, 33-58 and our own results showing the $\mathrm{Al}_{2} \mathrm{O}_{3}$ scale growth rate on different types of $\mathrm{Fe}, \mathrm{Ni}$ and $\mathrm{Pt}$ based alloys.

Figure 4: (a) The build up of sulfur at $\mathrm{Al}_{2} \mathrm{O}_{3} / \mathrm{FeCrAl}$ and $\mathrm{Al}_{2} \mathrm{O}_{3} / \mathrm{FeAl}$ interfaces as a function of oxidation time, where oxidation was carried out at $1000^{\circ} \mathrm{C}$ in $\mathrm{O}_{2}$. (b), (c) Representative AES spectra of the $\mathrm{FeCrAl}$ and $\mathrm{FeAl}$ surfaces respectively at steady state coverage.

Figure 5: The effect of cation doping on Al boundary diffusivity from creep studies compared with boundary diffusivity deduced from oxidation rates.

Figure 6: An example of oxygen isotope profiles from Quadakkers et al ${ }^{102}$ after two-stage oxidation of an $\mathrm{FeCrAl}$ alloy oxidized at $1000^{\circ} \mathrm{C}$ first in ${ }^{16} \mathrm{O}_{2}$ for 2.5 hours, then in ${ }^{18} \mathrm{O}_{2}$ for $5 \mathrm{hrs}$. 

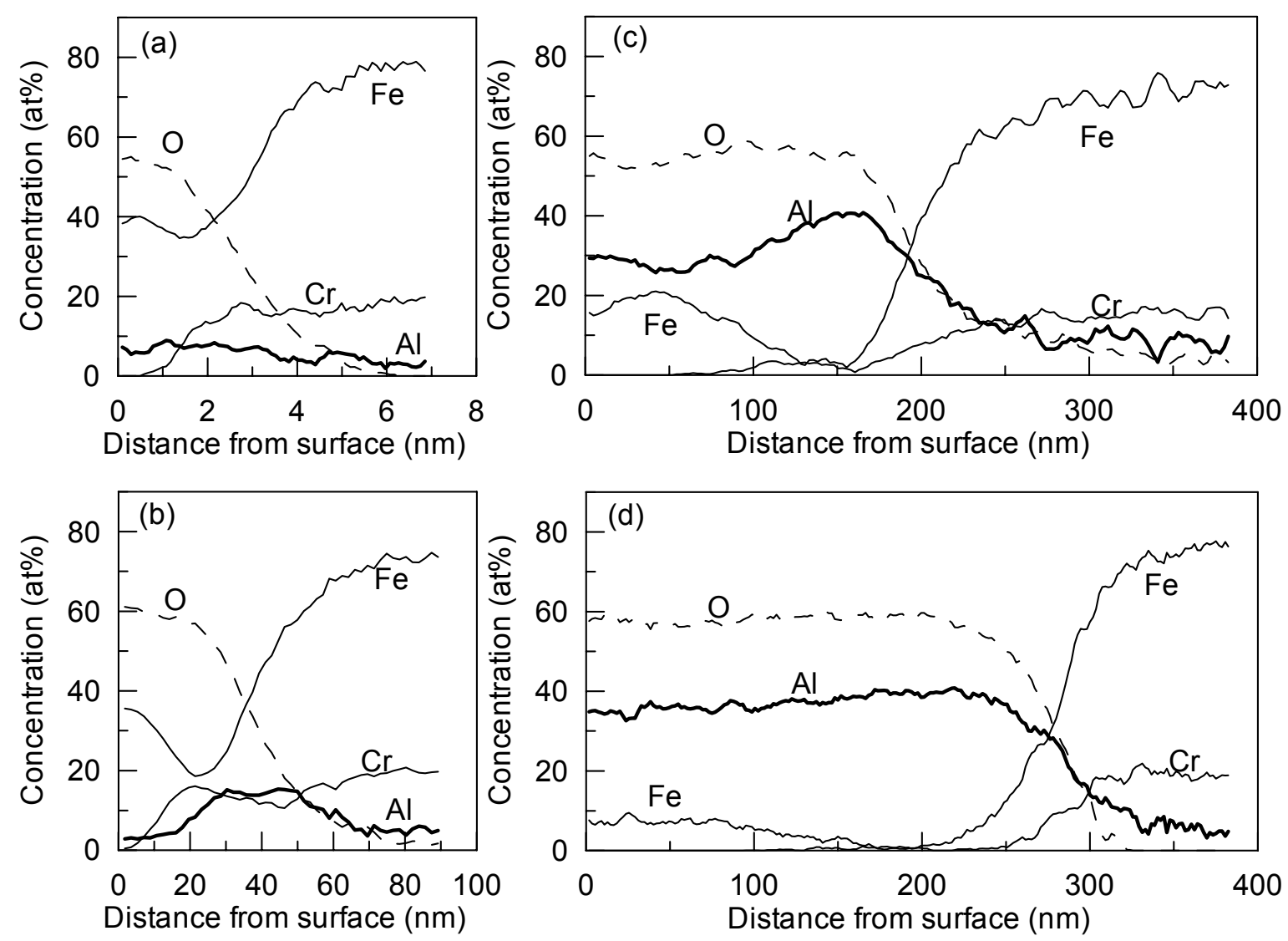

Figure 1: Auger depth profiles showing the composition of oxides on a FeCrAl alloy oxidized for different times in a $1000^{\circ} \mathrm{C}$ furnace in $\mathrm{O}_{2}$. (a) Initial surface before oxidation, (b) after $1 \mathrm{~min}$, specimen surface temperature, $\mathrm{T}$, at $670^{\circ} \mathrm{C}$, (c) after $3 \mathrm{~min}, \mathrm{~T}=970^{\circ} \mathrm{C}$ and (d) after $11 \mathrm{~min}, \mathrm{~T}=1000^{\circ} \mathrm{C}$. 


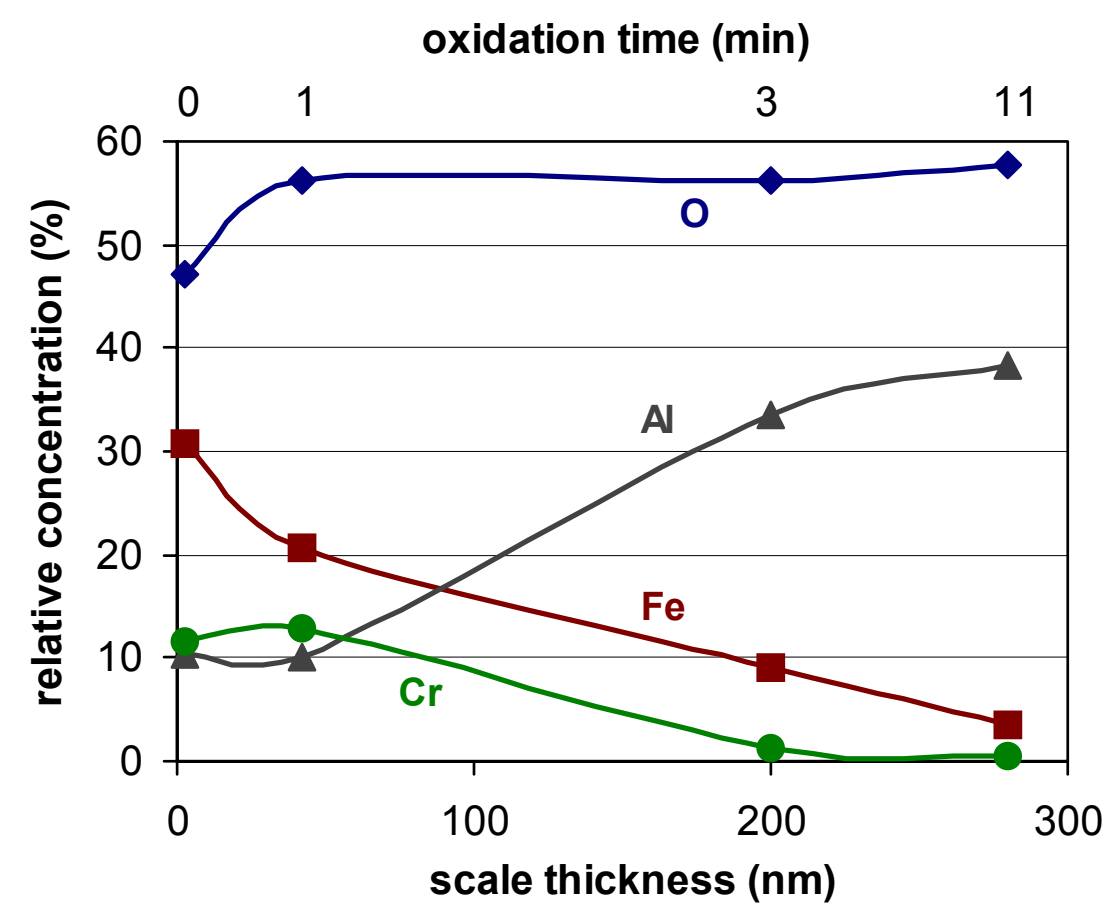

Figure 2: Concentration changes of different components in the oxide scale with time determined by integrating the oxide portion of the depth profile curves shown in Fig. 1. 


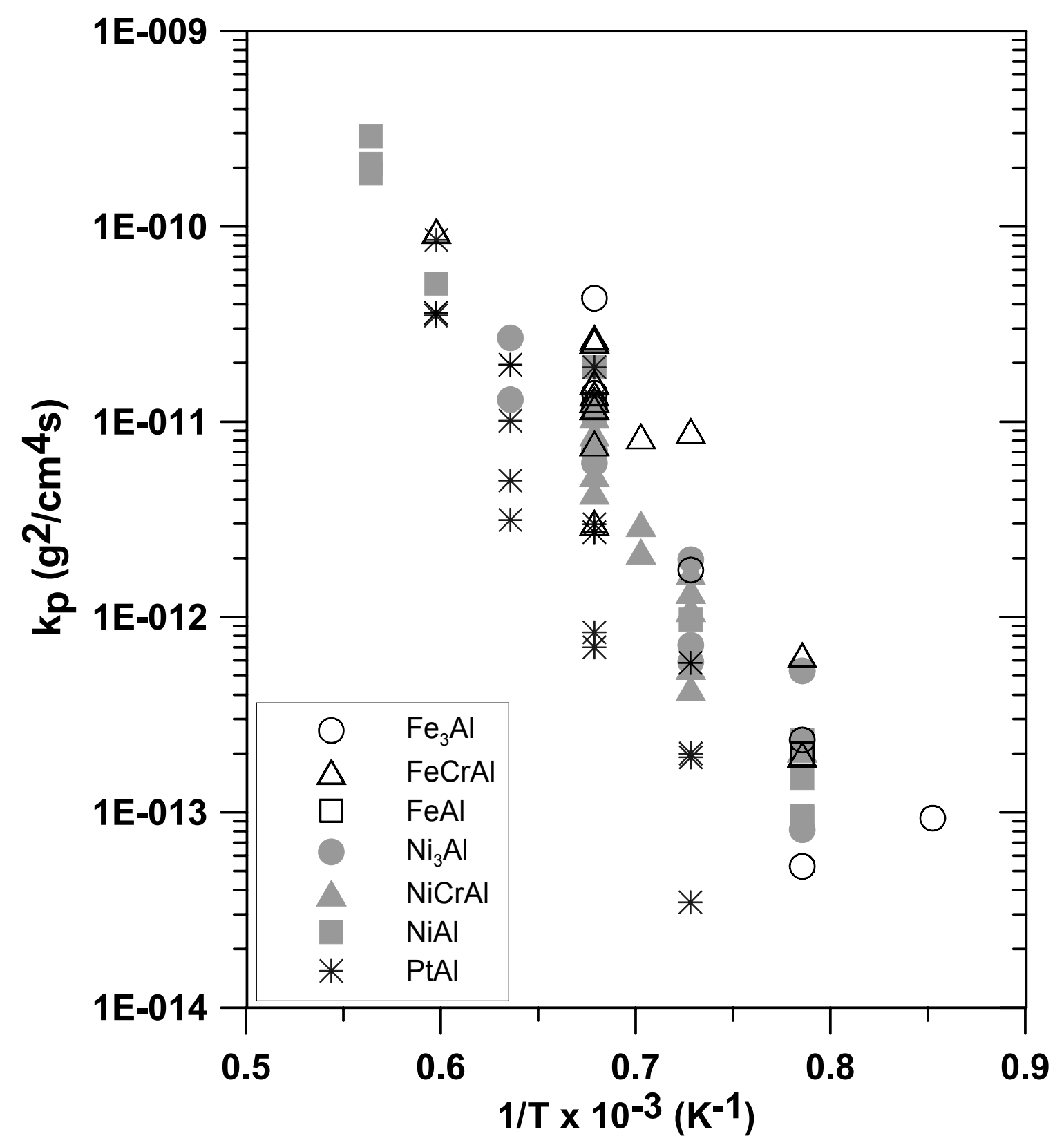

Figure 3: Parabolic rate constants from references 31, 33-58 and our own results showing the $\mathrm{Al}_{2} \mathrm{O}_{3}$ scale growth rate on different types of $\mathrm{Fe}, \mathrm{Ni}$ and $\mathrm{Pt}$ based alloys. 

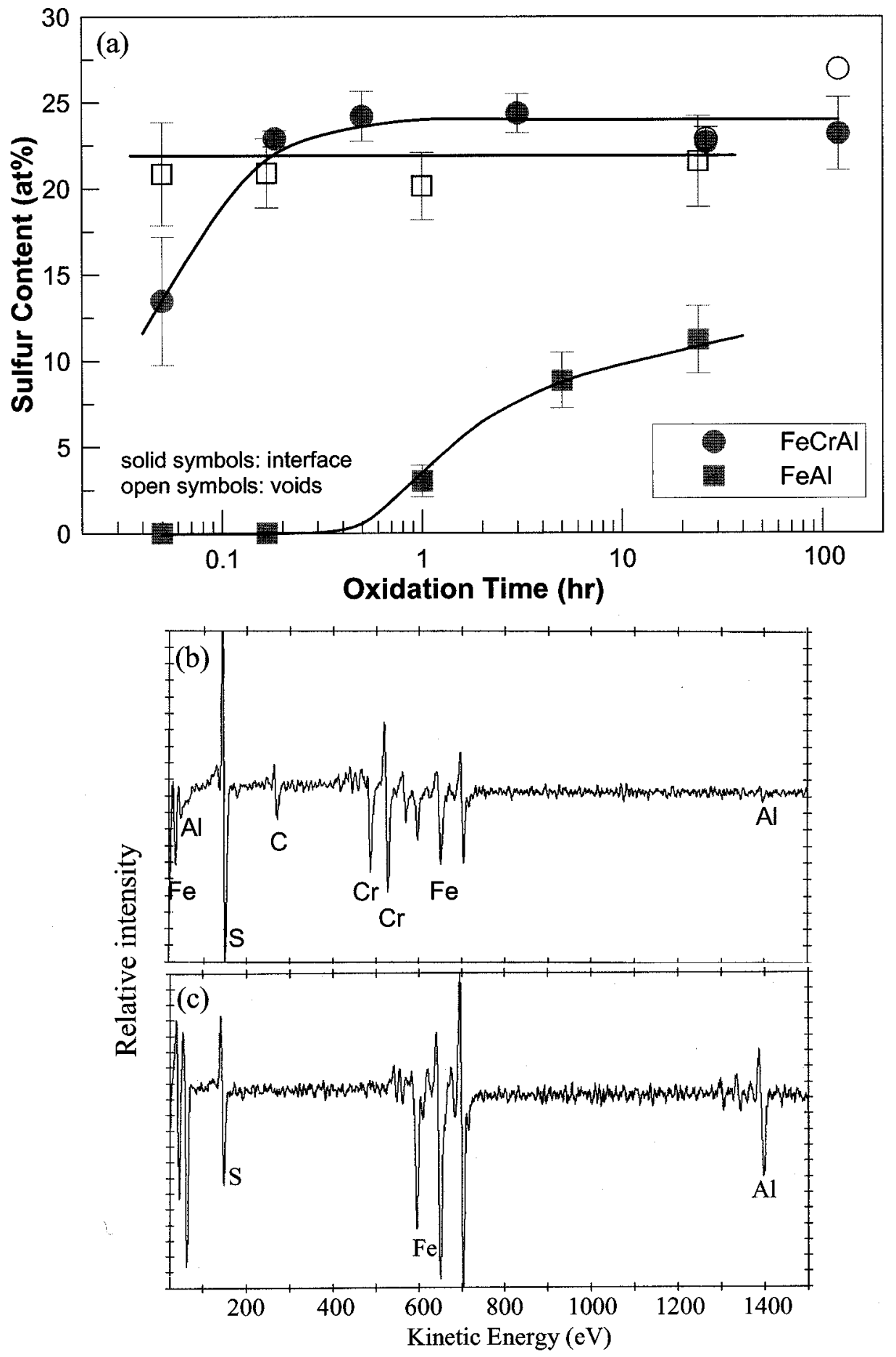

Figure 4: (a) The build up of sulfur at $\mathrm{Al}_{2} \mathrm{O}_{3} / \mathrm{FeCrAl}$ and $\mathrm{Al}_{2} \mathrm{O}_{3} / \mathrm{FeAl}$ interfaces as a function of oxidation time, where oxidation was carried out at $1000^{\circ} \mathrm{C}$ in $\mathrm{O}_{2}$. (b), (c) Representative AES spectra of the $\mathrm{FeCrAl}$ and $\mathrm{FeAl}$ surfaces respectively at steady state coverage. 


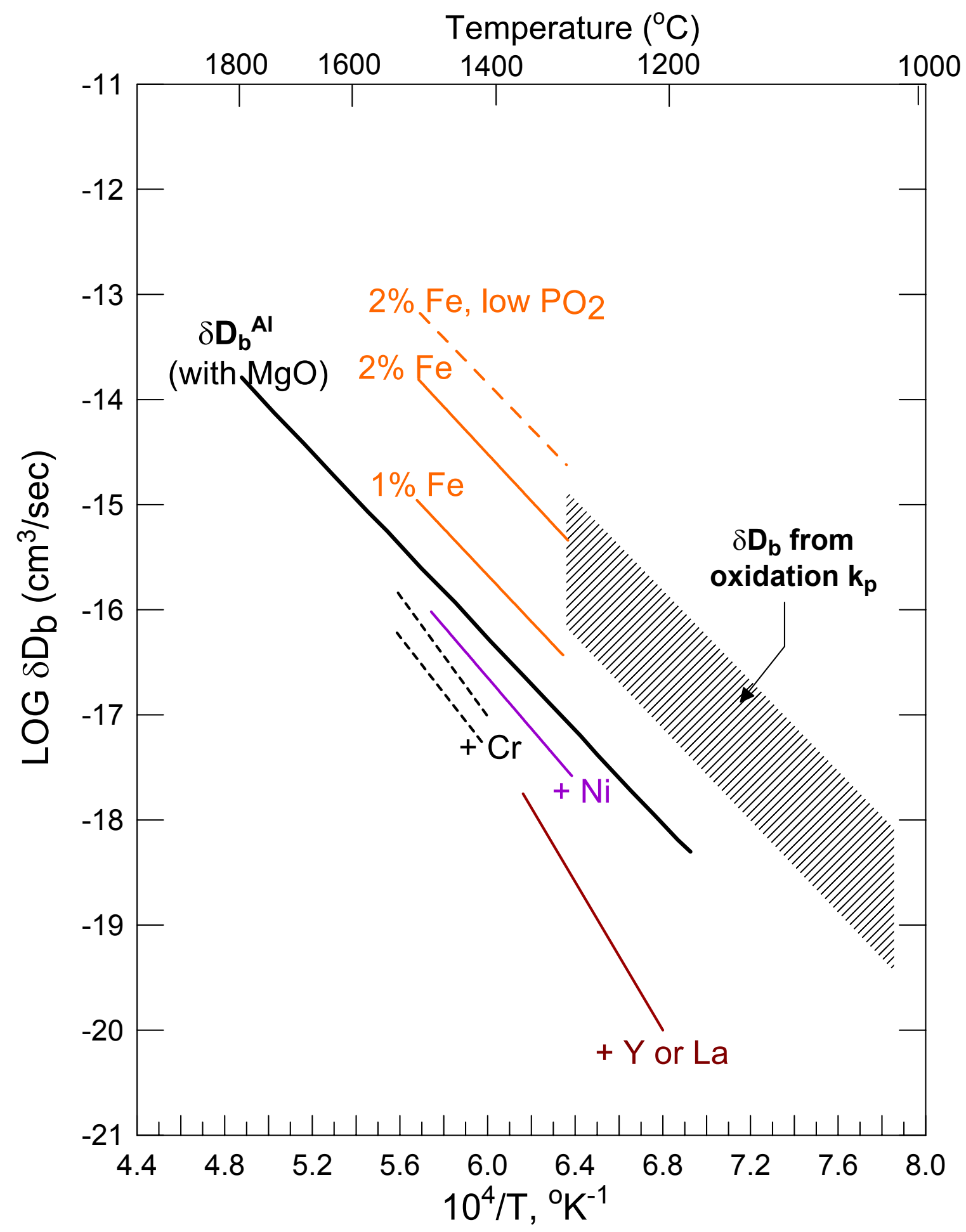

Figure 5: The effect of cation doping on Al boundary diffusivity from creep studies compared with boundary diffusivity deduced from oxidation rates. 


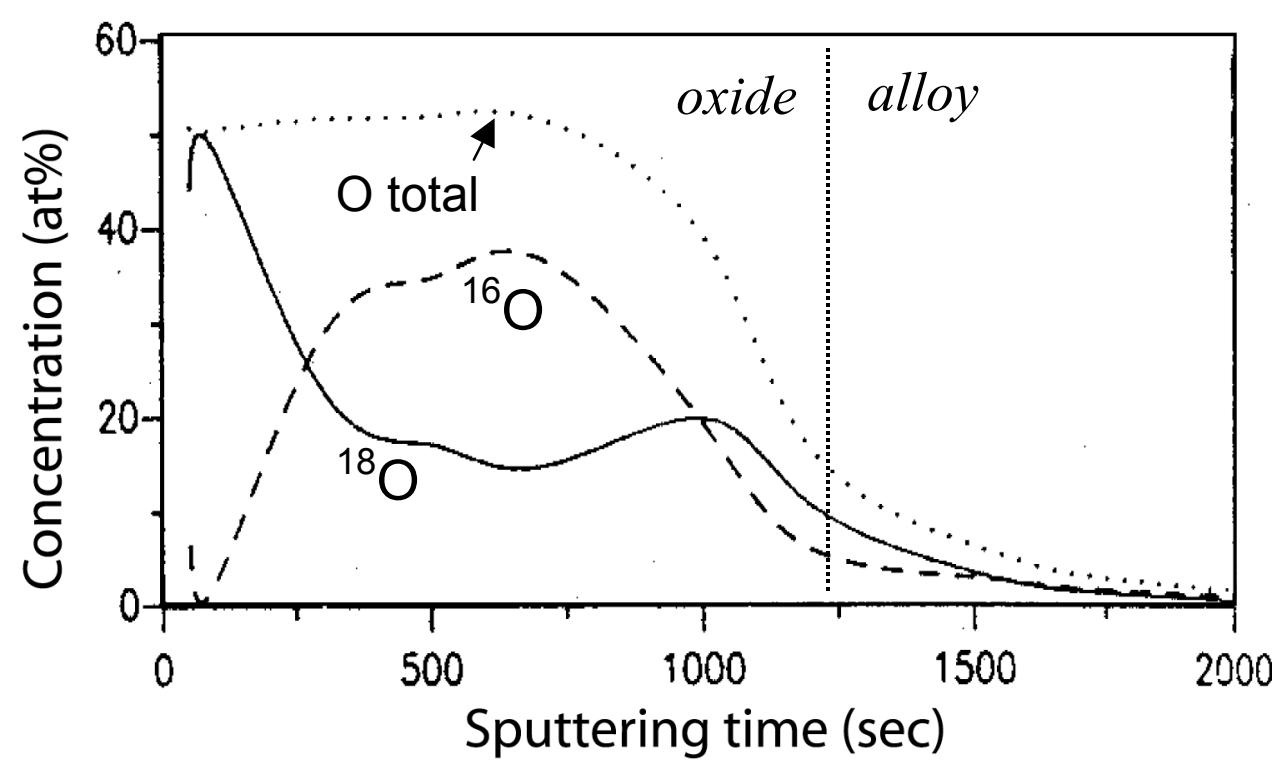

Figure 6: An example of oxygen isotope profiles from Quadakkers et $\mathrm{al}^{103}$ after two-stage oxidation of an $\mathrm{FeCrAl}$ alloy oxidized at $1000^{\circ} \mathrm{C}$ first in $16 \mathrm{O}_{2}$ for 2.5 hours, then in $18 \mathrm{O}_{2}$ for $5 \mathrm{hrs}$ 